rev.relac.int.estrateg.segur.6(1):13-46,2011

\title{
ORÍGENES DEL TERRORISMO GLOBAL: UNA PROPUESTA DE ANÁLISIS
}

\author{
Mourad Zarrouk*
}

\section{RESUMEN}

El presente artículo pretende analizar las causas lejanas del terrorismo procedente de países islámicos. Los orígenes del terrorismo global de hoy en día están bien anclados en la guerra contra la ex Unión Soviética que se desarrolló en tierras afganas. La gestión de la posguerra por los diferentes actores políticos involucrados en el conflicto contribuyó en la consolidación del yihadismo que se propagó aprovechando el vacío político y el abandono de Afganistán después de la guerra. Por otra parte, la represión del islamismo moderado en los países árabes provocó un proceso de radicalización que se alimentaba directamente de un discurso violento que vino a sustituir el discurso tradicional del islam político. La gestión del campo religioso por los regímenes de los países árabes e islámicos no aportó ninguna solución al problema del radicalismo, pues los ulemas oficiales no estaban capacitados para contrarrestar el avance del extremismo ni para sustituir a un actor político importante como los islamistas, cuyo discurso necesita actualmente una reforma profunda.

Palabras clave: Orígenes del terrorismo, Afganistán, islamistas, represión, islam oficial, discurso islamista.

* Profesor del Departamento de Estudios Árabes e Islámicos de la Universidad Autónoma de Madrid. zarroukmourad@yahoo.fr 


\begin{abstract}
This article seeks to analyze the distant causes of terrorism coming from Islamic countries. The origins of current global terrorism are well anchored in the war that took place in Afghanistan against the former Soviet Union. The handling of the post-war period by the various political actors involved in the conflict, contributed to the consolidation of the jihad, which spread taking advantage of the political vacuum and the neglect of Afghanistan after the war ended. On the other hand, the repression of moderate Islam in Arab countries triggered a process of radicalization that fed itself in a violent discourse that came to replace the traditional stance of political Islam. The handling of the religious realm by the regimes of Arab and Islamic countries did not bring any solution to the problem of radicalism, since the official Ulamas were not in a position to counteract the advance of extremism, nor to replace important political actors such as the Islamists whose discourse currently needs an in-depth reform.
\end{abstract}

Key words: Origins of terrorism, Afghanistan, Islamists, repression, official Islam, Islamic discourse

\title{
RESUMO
}

O presente artigo pretende analisar as causas distantes do terrorismo procedente dos países islâmicos. As origens do terrorismo global de hoje em dia estão bem ancorados na guerra contra a ex União Soviética que se desenvolveu no Afeganistão. A gestão da pós-guerra, realizada pelos diferentes atores envolvidos no conflito contribuiu para a consolidação do jihadismo que se difundiu aproveitando o vazio político e o abandono do Afeganistão depois da guerra. Por outro lodo, a repressão do islamismo moderado nos países árabes provocou um processo de radicalização que se alimentava diretamente de um discurso violento, o qual veio a substituir o discurso tradicional do islã político. A gestão do campo religioso pelos regimes dos países árabes e islâmicos não aportou nenhuma solução ao problema do radicalismo, pois os ulemás oficiais não estavam capacitados para evitar o avanço do extremismo nem para substituir um ator político importante como os islamitas, cujo discurso atualmente precisa de uma reforma profunda.

Palavras chave: Origens do terrorismo, Afeganistão, islamitas, repressão, islã oficial, discurso islamita.

"Je soutiens le maintien des dictatures les plus éclairées possibles -voire non eclairées du tout - En Egypte et en Arabie Saoudite plutôt que l'application, dans ces régions du monde, des principes démocratiques qui, dans l'immédiat, ne seraient que porteurs de désordres et de violence".

Alexandre Adler ${ }^{1}$

1. Le Figaro del 6 de septiembre de 2004.

ORÍGENES DEL TERRORISMO GLOBAL: UNA PROPUESTA DE ANÁLISIS 
"Los hombres a quienes se causa mal, se han de hacer más injustos".

Platón, La República.

\section{INTRODUCCIÓN}

El terrorismo² de Al Qaeda y grupos afines a esta organización hizo correr mucha tinta a lo largo de los últimos años. Sin embargo, ahora que George W. Bush y su equipo, que lanzó la guerra ciega contra el terrorismo, están relegados al trastero de la historia, que Osama Bin Laden murió en una operación delicada llevada a cabo por las fuerzas estadounidenses el 2 de mayo de $2011^{3}$ y que el uso del terrorismo como argumento para justificar el comportamiento agresivo de los EEUU en el escenario internacional ya no convence ni interesa como antes, procede indagar detenidamente en las causas profundas del terrorismo global. Por causas profundas entendemos las raíces de este fenómeno que podemos determinar analizando el comportamiento de varios actores políticos en diferentes etapas.

Los orígenes del terrorismo global están bien anclados en la guerra contra la ex Unión Soviética que se desarrolló en tierras afganas. La gestión de la posguerra por los diferentes actores políticos involucrados en el conflicto contribuyó en la consolidación del yihadismo que se propagó aprovechando el vacío político y el abandono de Afganistán después de la guerra. Por otra parte, la represión del islamismo moderado en la mayoría de los países árabes provocó un proceso de radicalización que se alimentaba directamente de un discurso violento ${ }^{4}$ que vino a sustituir el discurso tradicional del islam político. La gestión del campo religioso por los regímenes de los países árabes e islámicos, especialmente en Arabia Saudí, Egipto y Argelia, no aportó ninguna solución al problema del radicalismo ${ }^{5}$, pues los ulemas oficiales no estaban capacitados para

2. El terrorismo es tema de interés internacional desde 1937, cuando la disuelta Sociedad de las Naciones elaboró el Convenio para la Prevención y el Castigo del Terrorismo. En 1963 se elaboraron, bajo los auspicios de la ONU, 13 instrumentos universales para prevenir actos terroristas. Sin embargo, el concepto de terrorismo carece de definición reconocida por la comunidad internacional. El Comité Contra el Terrorismo de la ONU ha generado numerosos documentos acerca del terrorismo, pero al mismo tiempo reconoce que no se ha establecido todavía una definición a esta voz. Véase el documento generado por la Dirección Ejecutiva del Comité Contra el Terrorismo, Departamento de Información Pública de las Naciones Unidas, DPI/2375E - Enero 2005: http://www.un.org/spanish/docs/comites/ 1373/CTED_FAQs_SPA.pdf. Si el terrorismo, en tanto que violencia cometida por individuos o grupos para coaccionar o conseguir objetivos políticos y sociales, no es objeto de unanimidad, más difícil todavía es catalogar como actos terroristas algunas acciones llevadas a cabo por instituciones de Estados.

3. La operación llevada a cabo por las fuerzas especiales estadounidenses en Abbotabad contra Osama Bil Laden, en caso de confirmarse los detalles de la misma, se parece a una ejecución extrajudicial.

4. MAHFUZ, Mohammed (1988): Alladina zulimu, Londres: Riad El Rayyes Books.

5. Radicalismo entendido como "extremismo" que, en este caso, genera violencia, pero no como ideología "inherente" al islam, como pretenden algunos estudiosos que citaremos más adelante. Según Rafael del Águila, "toda política supone violencia, pero la que se aplica en nombre de la emancipación, la autenticidad o la democracia, es la 'verdadera'; es, incluso, 'admirable'. Véase: DEL ÁGUILA, Rafael (2008): Crítica de las ideologías. El peligro de los ideales, Madrid: Taurus, p. 55. 
contrarrestar el avance del extremismo ni para sustituir a un actor político importante como los islamistas, cuyo discurso necesita actualmente una reforma profunda.

\section{CAOS TERMINOLÓGICO Y COGNITIVO}

Cuando se habla del terrorismo procedente de países islámicos, se suele utilizar expresiones como terrorismo islamista, para atribuir este tipo de violencia a grupos islamistas en general. Otros prefieren vincularlo directamente a la religión islámica sin perder el tiempo con los matices, utilizando terrorismo islámico, y a los que no les gusta el simplismo optan por yihadismo, aunque no todos saben el significado de la voz árabe yihad. Mientras que los que pretenden ser políticamente correctos, optan por el eufemismo de terrorismo internacional o global ${ }^{6}$ y no faltan inventos más complejos como salafismo yihadista, yihadismo wahhabí u otras expresiones por el estilo.

Si nos fijamos en esta lista de conceptos, nos daremos cuenta de que reina un preocupante caos terminológico y conceptual. Muy poco importa a los que utilizan el concepto de terrorismo islamista que la organización Al Qaeda y los grupos afines a la misma no se definan como islamistas y que critiquen a estos últimos por privilegiar la política y dejar la lucha armada? . Los estudiosos $^{8}$ que han optado por terrorismo islámico, o han insinuado que las semillas del terror se hallan en el islam sin ofrecer otra exegesis de los textos sagrados de esta religión que justifique el terrorismo, están encasillados en una postura personal que solo coincide con la interpretación de los mismos terroristas y, por lo tanto, se trata de una opinión marginal. En cuanto a los investigadores que utilizan el concepto de yihadismo han de tener en cuenta todos los matices que conlleva el mismo, pues la voz yihad plantea un serio problema de polisemia que muchas veces se sortea utilizando la expresión de guerra santa inexistente en

6. Hemos optado por terrorismo global porque Al Qaeda y varios grupos terroristas afines a dicha organización han utilizado en sus textos y debates la expresión globalizar el yihad y golpear el enemigo lejano (EE.UU y aliados).

7. La guerra mediática entre Al Qaeda y Hamás se desencadenó cuando el partido islamista decidió participar en las elecciones. Hay varios textos y comunicados en árabe de Al Qaeda y grupos yihadistas que denuncian la posición de Hamás y el islamismo político en general. En este sentido, cabe destacar los discursos de Osama Bin Laden y Aiman Al Zawahiri al respecto y el artículo de Abu Ahmed Abderrahman Al Misri publicado por el Frente Islámico Mundial de Información bajo el título de "Gazza bayna Rayat al Dim'a wa rayat al 'Amala wal istijza'a", así como la advertencia de Abú Muhammad al Maqdisi dirigida a los líderes de Hamás en la página de minbar attawhid wal yihad: http:// www.tawhed.ws/ bajo el título de "Hamas sahhihu al asas wa jxaw Allah wa la tajxau Annas".

8. En plena conmoción tras los atentados perpetrados en los trenes de Madrid el 11 de marzo de 2004, Fernando Reinares y Antonio Elorza coordinaron una obra colectiva en la cual algunos estudiosos vinculan directamente la violencia con el islam: véase Elorza Domínguez, Antonio y Reinares Nestares, Fernando (eds.) (2004): El nuevo terrorismo islamista: del 11-S al 11-M, Madrid: Temas de hoy. En esta obra colectiva aparecen contribuciones como la de Olivier Roy: "Terrorismo islámico: las raíces doctrinales", pp. 147-176, de Antonio Elorza: "Anatomía de la yihad en el Corán y los hadices", pp. 269-294 y de Soha Abboud: "Creencias apocalípticas, cielo e infierno en el islam", pp. 313-333. Algunas conclusiones se pueden situar perfectamente en el ámbito de la islamofobia. 
los textos sagrados del islam ${ }^{9}$. Por otra parte, cabe señalar que tampoco todos los grupos yihadistas se definen como salafíes yihadistas, que entre los salafíes tradicionales (no violentos) y los yihadistas hay una enemistad insalvable y que aquellos a los que se les denomina hoy en día salafíes, yihadistas o no, no tienen nada que ver con el salafismo tal y como fue concebido por Jamal Eddin Al Afgani y Mohammed Abduh, padres del reformismo de finales del siglo XIX ${ }^{10}$.

Cada vez hay más expertos en universidades e instituciones occidentales que estudian los movimientos islamistas, grupos terroristas ubicados en países islámicos, perfiles de los terroristas y trasfondo ideológico de los mismos. Se trata de politólogos, sociólogos, criminólogos, psicólogos, especialistas en estudios árabes ${ }^{11}$ y otros expertos. Curiosamente, son muy pocos los expertos que manejan el árabe, principal vehículo de comunicación de los grupos terroristas objeto de los estudios en cuestión, ni otros idiomas como el urdú. El resultado, salvo contadas excepciones, no puede ser otro que la falta de análisis profundos y completos acerca de los orígenes del terrorismo global ${ }^{12}$.

Hay otro problema que impide rentabilizar los resultados de los estudios realizados por los mismos árabes sobre islam, islamismo y terrorismo global. Se trata del carácter selectivo de la política editorial y de traducciones que impiden una apertura real a la complejidad del mundo musulmán y a la diversidad de opiniones y de análisis ${ }^{13}$. También hay que reconocer que en Occidente se prefiere dar la palabra y escuchar a aquellos intelectuales árabes que escriben y se

9. Javier Jordán, por ejemplo, introduce este concepto inexistente en los textos sagrados del islam para referirse al yihad: "La percepción de los yihadistas es la de un islam acosado a nivel mundial que solo podrá salvarse si los musulmanes vuelven a lo que ellos consideran los orígenes de su fe y se movilizan en torno a la guerra santa"; véase: Jordán, Javier (2003): "Retos de la seguridad global", en: Revista Valenciana de Estudios Autonómicos, no: 41/42, pp. 23-31.

10. Por si fuera poco, los diccionarios y los recursos terminológicos inducen al error también. El Diccionario de la Real Academia Española define islamista como "perteneciente al integrismo musulmán", e integrista como "partidario de la intangibilidad de la doctrina". Precisamente el mayor reproche que se suele hacer a los islamistas dentro del mundo musulmán por diferentes corrientes ideológicas, incluidos los salafíes, es la integración en la doctrina de elementos ajenos a la misma. En cuanto a le Dictionnaire Géopolitique, coordinado por Yves Lacoste, los "islamistas, integristas o fundamentalistas son militantes que en el mundo musulmán quieren que el Estado y la sociedad sean conforme al derecho islámico. Practican la estrategia del reclutamiento de masas populares y luego recurren al terrorismo para provocar la caída de los regímenes que detienen el poder."

11. Cabe señalar que el hecho de ser arabista no quiere decir forzosamente dominar la lengua árabe. La configuración de los departamentos de Estudios Árabes e Islámicos o de Semíticas no contempla, en la mayoría de los países europeos, la didáctica de la lengua activa. De hecho, la lengua árabe no pasa de ser una asignatura más en estos departamentos.

12. La biblioteca del arabismo padece lagunas palpables en lo que se refiere a obras de base sobre el islam. Aunque no faltan obras que versen sobre diferentes aspectos del islam, muy pocos autores han manejado bibliografía en árabe. Como ejemplo, cabe recordar que la voluminosa obra del arabista Félix María Pareja: Islamología (Editorial Razón y Fe, Madrid, 1952), considerada como un libro clave en el ámbito del arabismo español, contiene en la larguísima lista bibliográfica una sola referencia en árabe y se trata además de un libro sobre nacionalismo en Marruecos sin ninguna relación con el islam.

13. En general, las traducciones del árabe a las lenguas vernáculas no son abundantes y se realizan sobre todo dentro del ámbito del orientalismo, siendo la literatura el campo más traducido. Véase.: Zarrouk, Mourad (2007): "Oriente traducido: nuevas perspectivas, in: Afkar ideas: Revista trimestral para el diálogo entre el Magreb, España y Europa, №. 
expresan en lenguas vernáculas, que llegan a las mismas conclusiones que los estudiosos y analistas occidentales. Así que muchos intelectuales árabes laicos desfilaron a lo largo de dos décadas por universidades y fundaciones en países occidentales. Hablaban casi siempre del islam como origen del mal o de los islamistas como enemigos de la democratización de los países árabes e islámicos. Llevando nombres árabes o musulmanes podían rebasar los límites del discurso prudente y ser islamófobos ${ }^{14}$. Obviamente, este discurso era compatible, y los es todavía, con el diagnóstico precipitado del fenómeno de los movimientos islamistas y el de los grupos terroristas. Este tipo de estudiosos e intelectuales no presentó un análisis matizado de una coyuntura política compleja ni ayudó a buscar soluciones a la amenaza terrorista. Se trata del eco de las voces occidentales más autorizadas que reducen la complejidad de un fenómeno en las dicotomías de siempre: emancipación/oscurantismo, progresistas/retrógradas, modernidad/fundamentalismo, etc. Esta situación encarna, sin duda, una subordinación cultural digna de la época colonial, situación impecablemente descrita por Jean Paul Sartre cuando hace casi medio siglo escribió: "No hace mucho tiempo, la tierra estaba poblada por dos mil millones de habitantes, es decir quinientos millones de hombres y mil quinientos millones de indígenas. Los primeros disponían del Verbo, los otros lo tomaban prestado" (Fanon, 1961: 5).

\section{LAS SEMILLAS DEL TERROR}

\subsection{La guerra de Afganistán: yihad en plena Guerra Fría}

Cuando se habla de la violencia que originó el terrorismo global, se adopta una periodización incongruente. Algunos análisis arrancan justo después de la caída del muro de Berlín; otros remontan al surgimiento de los Hermanos Musulmanes en Egipto hacia el año 1928, pues de este movimiento islamista salieron otras formaciones más violentas, y algunos estudios procuran vincular directamente, a través de algunas interpretaciones marginales, la religión musulmana con la violencia.

Cada uno de estos puntos de vista puede basarse en una serie de acontecimientos que tuvieron lugar antiguamente o en diferentes fases del siglo XX. De hecho, desde siempre hubo interpretaciones violentas y extremistas de algunas aleyas del texto alcoránico. Estas interpretaciones surgían en diferentes contextos históricos y, en este sentido, procede resaltar, entre otros ejemplos,

16, 2007-2008 , págs. 52-53. Según las estadísticas de la UNESCO, entre 1980 y 2011 se han traducido del árabe al español 993 títulos, de los cuales 641 son sobre literatura y 122 sobre religión. Siguiendo el mismo orden, se han traducido del árabe al inglés en el mismo periodo 551 obras literarias y 407 títulos sobre religión. Del árabe al francés se han traducido 983 obras literarias y 582 títulos sobre religión. Véase el Index Translationum de la UNESCO: http:/ /portal.unesco.org/culture/fr/ev.php-URL ID=7810\&URL_DO=DO TOPIC\&URL SECTION=201.html.

14. Se trata de universitarios, escritores, poetas, periodistas, etc. Véase: MEDDEB, Abdelwahab (2002): La maladie de I'islam, Paris: Seuil. 
la experiencia extremadamente violenta de los jariyíes ${ }^{15}$. Los que apuntan a la organización de los Hermanos Musulmanes como responsable del desencadenamiento de la violencia en el mundo musulmán, suelen poner especial hincapié en las escisiones que sufrió esta organización desde el principio originando, directa o indirectamente, el surgimiento de grupos extremistas tales como: Al yama'a al islamiyah ${ }^{16}$, Al yihad ${ }^{17}$, o yama'at al muslimín, conocida como attakfir wal hiyrah ${ }^{18}$. En cuanto a los estudiosos que piensan que los orígenes del terrorismo global no van más allá de la caída del muro de Berlín, parten del fenómeno del recrudecimiento de los atentados perpetrados por terroristas musulmanes y, especialmente, la utilización del suicidio como procedimiento de ejecución de tales atentados. Sin embrago, la indagación en los orígenes del terrorismo global tiene que centrarse en una combinación de razones y no solamente en un factor único. En otras palabras, ha habido una acumulación de experiencias y de hechos que llevaron más tarde al surgimiento de este fenómeno. Dicho esto, consideramos el comportamiento de los EE.UU. y de sus aliados árabes y musulmanes durante la Guerra de Afganistán, en plena ocupación rusa, como una causa directa de la preparación del terreno a los grupos radicales.

Sin lugar a dudas, los políticos norteamericanos que tomaron la decisión de utilizar los muyahidines afganos y árabes para contrarrestar la hegemonía de la ex Unión Soviética en Afganistán asumen una gran responsabilidad en lo que se refiere a la radicalización de dichos elementos. Lo que iba

15. Los Jariyíes aparecieron como grupo a raíz de la primera guerra civil en la historia del islam entre el cuarto califa ortodoxo Alí Ibnu Abi Taleb y Mu'auiya Ibnu Abi Sufian hacia el año 657. Más tarde desarrollaron sus propias interpretaciones de los textos sagrados creando así una de las corrientes más extremistas de la historia del islam.

16. Este grupo radical nació en las universidades egipcias a principios de los años setenta en plena crisis del islam político. Al principio este grupo era minoritario en comparación con los movimientos estudiantiles de corte marxista o nacionalista naserista, pero a partir del año 1973 ganó mucho terreno tanto en las universidades como en otros espacios. Hacia el año 1977, un grupo reducido de militantes de Al yama'a al islamiyah la abandonó para reintegrarse en los Hermanos Musulmanes. Hacia el año 1979 Al yama'a al islamiyah y Al Yihad deciden armonizar esfuerzos para derrocar el régimen de Anuar Sadat. Fue cuando este grupo se apartó de las orientaciones del salifismo tradicional designando de paso como líder del mismo a Omar Abderrahmán, quien está actualmente en una cárcel en los EE.UU acusado de participar en el atentado contra el World Trade Center el 26 de febrero de 1993. Véase: SHEHATA, Siam (1988): Al ‘unf wal jitab addini, El Cairo. Dar Sina, y el sitio web del grupo: www.egyig.com

17. Grupo extremista que se configuró en las cárceles egipcias en los años setenta. Al obtener el indulto del presidente egipcio Anuar Sadat sus miembros empezaron a integrar pequeñas células en todo el territorio egipcio. Este grupo terrorista perpetró una serie de atentados en Egipto y en Pakistán. En el año 1981 consiguieron asesinar al entonces presidente de Egipto Anuar Sadat. Uno de los líderes de Al Yihad más destacados es Aiman Al Zawahiri. Véase: MAHFUZ, Mohammed (1988): op.cit., pp. 242-280.

18. Yama'at al muslimun o takfir wal hiyra, es uno de los grupos más extremistas en el mundo islámico. Apareció en las cárceles egipcias a partir de 1965 después de que Jamal Abdennaser procediera a arrestos masivos en filas de islamistas egipcios. La ejecución de Sayyed Qutb y otros compañeros suyos y la tortura de los presos islamistas originó la radicalización de un grupo de reclusos que adoptaron una posición de enemistad y rechazo, no solamente hacia el régimen, sino hacia la misma sociedad egipcia que tildaban de hereje. Este grupo fue liderado al principio por un alfaquí extremista, Alí Ismael, quien más tarde reconsideró sus puntos de vista, lo que le llevó a abandonar este grupo. Shukri Ahmed Mustafá pasó a ser el nuevo líder de este grupo que se apartó de la sociedad después de la excarcelación de sus miembros por considerarla hereje. Después del asesinato del ministro de asuntos religiosos egipcio Mohammed Husein Addahabi, Shukri Mustafá y varios compañeros suyos fueron inculpados y ejecutados. Véase: MAHFUZ, Mohammed (1988): Alladina zulimu, Londres: Riad El Rayyes Books 
a ser una guerra de resistencia afgana contra los invasores rusos se convirtió en un enfrentamiento bélico indirecto entre los dos polos que lideraban el mundo. EE.UU y los países árabes y musulmanes que estaban en su órbita durante la Guerra Fría decidieron colaborar para facilitar la tarea a los guerrilleros afganos proporcionándoles armas, dinero y muyahidines voluntarios procedentes de los países árabes. Esta alianza contra natura y este bricolaje digno de las luchas oscuras que caracterizaban la Guerra Fría tuvo consecuencias nefastas a largo plazo. En las filas de los voluntarios árabes no faltaban elementos extremistas que tenían objetivos que iban más allá de la Guerra de Afganistán. En este sentido, cabe recordar lo que escribió Imam Abdulaziz, alias doctor Fadl ${ }^{19}$, en su crítica a la organización Al Qaeda: ${ }^{20}$

El nombre de Al Qaeda apareció en el año 1987 gracias al xeij Abdallah Azzam y con el dinero recaudado por Osama Bin Laden con el claro objetivo de luchar contra la invasión soviética en Afganistán. En el año 1989 Bin Laden consigue que un grupo de voluntarios árabes le rinda pleitesía y se convierte en el emir de esta organización. Sus objetivos ya no se limitaban a Afganistán, lo cual se corroboró en una gira que inició en el Yemen del sur en el año 1990. Luego, en el año 1993 se fue a Sudán y allí empezó a aspirar a un choque con las grandes potencias mundiales, lo cual le llevó a aliarse con Aiman Al-Zawahiri en el año 1998 creando los dos el Frente Mundial para la Lucha contra los Judíos y los Cruzados antes de que se produjeran los ataques del 11 de septiembre de 2001, cuando la organización y sus dos líderes se adentraron en un túnel oscuro donde permanecen hasta hoy en día ${ }^{21}$.

La propaganda yihadista consentida y orientada por los países árabes, con la bendición norteamericana, fue arrolladora y permitió captar muchos voluntarios que más tarde se enrolaron en las filas de los muyahidines. Es muy significativo el testimonio de uno de los primeros voluntarios árabes que llegaron a Afganistán, Abu Al Walid Al Masri, que desapareció después de la toma de Kabul y la caída del régimen talibán en Afganistán: "Los términos yihad y muyahidines se propagaron en los periódicos occidentales y árabes. Nuestros sentimientos se encandilaron y empezamos a seguir de cerca este asunto [la guerra de Afganistán] indagando en todas las fuentes posibles" $(\text { Masri, 2006) })^{22}$.

19. Este cirujano egipcio se considera como el ideólogo de la organización terrorista Al Yihad a la cual pertenecía Aiman Al Zawahiri. Después de publicar el libro de Al Umdah fi I'dadi al 'uddah, considerado como una obra clave de los grupos yihadistas, reconsideró paulatinamente sus "teorías" publicando al final el libro de tarshid al 'amal al yihadi lo que originó un enfrentamiento directo con Aiman Al Zawahiri, quien desde su escondite escribió el libro de Attabri’a, a lo cual Imam Abdulaziz responde desde la cárcel egipcia donde se halla actualmente con un texto que lleva el título de Atta'riyah, publicado íntegramente, en varios episodios, en el periódico árabe londinense Ashark al Awsat.

20. Las citas en árabe han sido traducidas al castellano por el autor.

21. http://www.asharqalawsat.com/details.asp?issueno $=10950 \&$ article $=495715$

22. Se trata del libro inédito de Abu Al Walid Masri (2006): tratarah fawqa saqfi Al 'Alam. Documento hallado por las fuerzas norteamericanas en un refugio de Al Qaeda en Kandahar, y publicado por el periódico árabe Ashark Al Awsat (cuarto episodio): http://www.asharqalawsat.com/details.asp?issueno=10195\&article=389254. 
Otro veterano de la guerra de Afganistán, un argelino llamado Boujemaa Bounoua, que utiliza el apodo de Abdallah Anas y que actualmente se encuentra en Londres, donde tiene el estatus de refugiado ${ }^{23}$, relata en su libro sobre el nacimiento de los afganos árabes cómo tomó la decisión de participar en dicha guerra. Este hombre se incorporó en la guerrilla afgana tras haber leído en su país, Argelia, una fatua (dictamen) de varios ulemas, entre ellos el ulema saudí allegado a la institución monárquica saudí Ben Baz, que en las páginas de una revista kuwaití llamaba a los musulmanes a luchar contra el Ejército Rojo porque se trataba de una obligación vinculante (Anas, 2002: 14).

Sin lugar a dudas, el término muyahidines tenía una carga semántica positiva, tanto en los medios de comunicación árabes, como en los occidentales. Las imágenes de los civiles masacrados por el Ejército Rojo y la de los guerrilleros, con armamento ligero, atrincherados en las montañas de Afganistán, eran suficientes para que la ex Unión Soviética perdiera la batalla mediática mucho antes de perder la guerra. La magia de la imagen orientaba la opinión pública internacional según las conveniencias de aquella coyuntura que conoció un peculiar juego de alianzas.

Los servicios secretos paquistaníes allanaban el camino a voluntarios árabes para cruzar la frontera con Afganistán; los países del Golfo donaban dinero, publicaban dictámenes y animaban las grandes familias a colaborar en dicha lucha. De allí el interés del joven Osama Bin Laden, hijo de un multimillonario empresario saudí por la lucha contra los soviéticos. Israel por su parte vendió las armas de fabricación rusa que había conseguido en sus victorias militares contra los árabes, especialmente la de la Guerra de $1967^{24}$. En cuanto a Egipto, la ocasión era propicia para el régimen de Anuar Sadat, a fin de pasar la página de los acuerdos de Camp David y la polémica visita a Jerusalén y, de paso, apaciguar los ánimos de los islamistas e identificar, en el marco de la coyuntural alianza con los muyahidines egipcios, a aquellos elementos susceptibles de recurrir a métodos violentos para desestabilizar el régimen egipcio. Los líderes árabes y musulmanes, preocupados por la emergencia de corrientes islamistas inspiradas en la revolución iraní, procuraban quitar argumentos a sus rivales islamistas demostrando su compromiso con la causa afgana.

Ante esta situación no hay que extrañarse de las recomendaciones de la Organización de la Conferencia Islámica $\mathrm{OCl}$, integrada por países árabes y musulmanes, en su mayoría aliados de los Estados Unidos durante la Guerra Fría. En este sentido, cabe resaltar la claridad con que se trató la cuestión afgana en las diferentes reuniones de la $\mathrm{OCI}$ en comparación con otras causas. Así pues, en la Declaración de la Meca, al final de la cumbre de esta organización celebrada en Arabia Saudí del 25 al 28 de enero de 1981, los países musulmanes decidieron: "apoyar el

23. Abdallah Anas tiene el estatus de refugiado en gran Bretaña desde 1994, véase: http://www.aawsat.com/ details.asp? section $=28 \&$ article $=88458 \&$ issueno $=8481$.

24. Algunos autores se refirieron a la venta del armamento ruso por parte de Israel. Anas Abdallah escribió en su libro que los combatientes afganos preferían las ametralladoras Kalashnikov egipcias a las que procedían de China (ANAS, 2002: 32). 
pueblo afgano en su yihad"25. Tres años más tarde, se celebró otra cumbre de la OCl en Casablanca. Esta vez el representante de los muyahidines afganos, Burhan Addin Rabbani, tomó la palabra en presencia de los líderes árabes y musulmanes y, también en presencia del entonces Secretario General de la ONU, Pérez de Cuellar. La Declaración Final de dicha cumbre no dejaba lugar a dudas: "Los participantes han seguido con mucho interés la intervención de Burhan Addin Rabbani, representante de los muyahidines afganos que habló de la situación de la resistencia afgana y de su lucha legítima para liberar su patria ocupada y agradeció a los países islámicos el apoyo prestado a los muyahidines"26.

La OCl no cambió de postura en ningún momento a lo largo de este conflicto. Pero cabe señalar que durante la Guerra de Afganistán, el mundo islámico conoció una serie de acontecimientos que no merecieron todo el interés de la Liga de los Países Árabes ni el de la OCI. Israel, que ocupaba territorios árabes, bombardeó Irak en 1981, invadió El Líbano en 1982, bombardeó Túnez en 1985 y Estados Unidos atacó Libia en 1986. Pero como el objetivo era hundir la ex Unión Soviética en Afganistán, el concepto del yihad fue utilizado de una manera puntual y selectiva, pues era necesario para llevar a buen término el plan estadounidense en la zona, para apaciguar los ánimos en los países islámicos y para reclutar a voluntarios, y así fue.

\subsection{La trágica gestión de la posguerra}

Consumada la victoria de los muyahidines, el Ejército Rojo abandonó Afganistán en febrero de 1989. Abdallah Anas, uno de los muyahidines árabes que estaban en el norte de Afganistán, veía con los prismáticos cómo salían los rusos de ese país aquel 14 de febrero resumiendo así, desde la perspectiva del participante y del testigo ocular, el desenlace del conflicto:

Muchos factores han permitido la victoria final sobre la Unión Soviética. Factores externos como el papel de Pakistán, la retaguardia de los muyahidines afganos, de dónde conseguían armamento y dónde se entrenaban, el papel desempeñado por los países árabes e islámicos y el papel de los países occidentales encabezados por los Estados Unidos, que respaldó a los muyahidines militar y políticamente (Anas, 2002: 86).

Los voluntarios árabes que participaron en la guerra de Afganistán no superaban los 2.000, sin contar los otros árabes que permanecieron en Pakistán para colaborar con la guerrilla, entre médicos, enfermeros, contables, etc. Sin embargo, la victoria de los afganos animó a otros jóvenes árabes a ir a Afganistán que se iba a convertir en un amplio campo de entrenamiento para

25. Declaración de la Meca, archivo de la OCl: http://www.oic-oci.org

26. Declaración Final de la cumbre de la OCl celebrada en Casablanca del 16 al 19 de enero de 1984. Archivo de la OCl: http://www.oic-oci.org, consultado el 15 de julio de 2010.

ORÍGENES DEL TERRORISMO GLOBAL: UNA PROPUESTA DE ANÁLISIS 
quienes querían prepararse para una próxima guerra. A finales de 1989, Abdallah Azzam, el mentor palestino de los muyahidines árabes y uno de los actores más activos de la guerra de Afganistán, fue asesinado en un atentado en Pishawer, Pakistán. Abdallah Azzam, a través de la Oficina de Servicios que había creado durante la guerra, consiguió coordinar al principio el movimiento de los árabes afganos hasta que empezó a perder el control de la situación con la llegada de nuevos árabes.

Los pequeños grupos de muyadines empezaron a constituirse paulatinamente en función de las nacionalidades, al mismo tiempo que cada grupo pasó a contar con su propio líder. Luego empezaron las escisiones. Era prácticamente imposible controlar aquellos jóvenes árabes debido a sus convicciones y trasfondo ideológico. Sus planteamientos acerca del futuro del islam y de la construcción de un Estado islámico eran más confusos todavía. Si añadimos las infiltraciones profundas de los servicios de seguridad en estos grupos, nos daremos cuenta de los problemas de organización experimentados por los muyahidines en Afganistán y, por lo tanto, de la poca influencia del xeij Abdallah Azzam sobre la agrupación de los árabes (Masri, 2006).

Tanto en Afganistán como en Pakistán los augurios de un auténtico caos eran palpables. Entre la retirada del Ejército Rojo en 1989 y la caída del régimen pro soviético en Kabul en 1992, las facciones afganas sabían que iban a entrar en una guerra civil porque lo único que les unía era la lucha contra los comunistas afganos y la ex Unión Soviética y, de hecho, se estaban preparando para la siguiente contienda. Los árabes que deambulaban en las calles de Pishawer buscaban una nueva causa para reanudar su propia lucha en otro terreno si cabía la posibilidad ${ }^{27}$. Algunos querían luchar en Palestina, otros contra los regímenes árabes y no faltaban quienes tenían la obsesión de atacar a los Estados Unidos como Osama Bin Laden. Este último no se encontraba cómodo actuando a la sombra de Abdallah Azzam por lo que rompió con él antes del atentado de 1989 que acabó con la vida de este último. Abdallah Anas describe el Pishawer de principios de los años noventa:

En Pishawer ya había muchas corrientes. Aparecieron nuevos centros de acogida de muyahidines, algunos con una orientación takfiri ${ }^{28}$. Otros centros de acogida de procuraban denigrar los muyahidines afganos so pretexto de que eran herejes y autores de bida'a ${ }^{29}$. Uno de los nuevos grupos que descubrí en Pishawer era la organización Al Qaeda. Oía hablar de Al Qaeda y de su líder Osama Bin Laden (Anas, 2002: 90-91).

27. ATTAOUIL, Kamil (2007): Al qaeda wa ajawatuha, Beirut: Dar Assaki, pp. 50-69.

28. Los grupos que pertenecen a esta corriente pueden llegar a calificar de herejes a otros musulmanes para excluirles o, incluso, para actuar contra ellos directamente.

29. Bida'a es la innovación que se atribuye erróneamente a los preceptos del Islam. 
Ninguno de los actores que orquestaron aquel golpe letal a la ex Unión Soviética en Afganistán se preocupó por la paz en ese país ni por la reintegración de los voluntarios árabes en sus respectivos países ni tampoco por la llegada de la segunda generación de muyahidines árabes más radicales y sin objetivos concretos, justo cuando los antiguos voluntarios empezaron a abandonar Afganistán ${ }^{30}$. Estados Unidos, que neutralizó la ex Unión Soviética, intentaba encauzar el nuevo conflicto entre facciones afganas hacia sus intereses inmediatos y los países árabes optaron por perseguir a los guerrilleros que volvieron de Afganistán. En Egipto, por ejemplo, el régimen decidió inculpar a todos los que habían participado en la guerra contra la ex Unión Soviética porque el régimen pretendía dirigir un golpe preventivo a dichos elementos aguerridos que volvieron a su país. Así pues, en 1992, se abrió el caso "los retornados de Afganistán", lo que llevó a muchos jóvenes árabes a permanecer en Pakistán y Afganistán y a sumarse a la segunda ola de los árabes que empezaron a llegar a Afganistán a partir de mediados de los años noventa, con el fin de la guerra de Bosnia, y el recrudecimiento de la persecución de los grupos armados en Argelia y de yihadistas en Libia y en Sudán ${ }^{31}$.

Curiosamente, parece que cuando Bin Laden enrolaba a nuevos guerrilleros y creaba nuevos campos de entrenamiento en el Yemen y en Sudán, nadie se percató de lo que se avecinaba. Los acontecimientos que sucedieron después de la Guerra de Afganistán allanaron el camino a la globalización del odio y a la configuración de un discurso que, esta vez, recriminaba a Occidente y lo culpaba de todos los males que azotaron a los musulmanes. Se trata de elementos que podemos resaltar en los discursos de los yihadistas en función de la coyuntura, como el golpe de Estado en Argelia apoyado tácitamente por los países occidentales, la segunda Guerra del Golfo, la pasividad de Occidente ante la limpieza étnica en Bosnia, la Guerra de Chechenia, Las continuas agresiones cometidas por Israel contra los palestinos, etc. La caída del muro de Berlín fue determinante en lo que se refiere a la visibilización del islam y de los movimientos islamistas. En plena tensión que se vivía en diferentes países islámicos, el exsecretario general de la OTAN, Willem Werner Hubert "Willy" Claes, dijo: "el islam es tan peligroso como lo fue el comunismo" y "La OTAN es mucho más que una alianza militar. Está comprometida a defender los principios básicos de la civilización que vinculan a EE.UU y Europa Occidental"32. Este tipo de declaraciones no hacía más que ampliar el abismo que separa Occidente del mundo islámico y, especialmente, de un nuevo bando en construcción.

Algunos veteranos de la Guerra de Afganistán se habían ido con Bin Laden; otros volvieron a participar en otras guerras en Somalia, Bosnia y Chechenia y otros se fueron a Gran Bretaña, precisamente a Londres o Londonistán ${ }^{33}$, donde desarrollaban una actividad de carácter doctrinal

30. ATTAOUIL, Kamil (2007): op.cit, pp. 50-69.

31. Ibid., p. 273.

32. The Guardian del 3 de febrero de 1995.

33. Así llamaban los servicios secretos franceses la capital británica a mediados de los años noventa, debido a las agrupaciones radicales que pululaban en dicha ciudad. Véase: RADU, Michael (2010): "Spectres européens Le 'Londonistan' en tant que producteur et exportateur d'islamisme", in: Outre-Terre, no 24, pp. 431-436. 
y de apoyo logístico a los grupos implicados en conflictos armados, y otros excombatientes volvieron a llevar una vida normal.

\subsection{La represión del islamismo}

\subsubsection{Dictadores contra islamistas}

Aunque el islamismo o islam político organizado había nacido en 1928 con la creación de los Hermanos Musulmanes por Hasan Al-Banna, se puede decir que la regeneración de esta corriente coincidió con el principio de la decadencia del panarabismo después de la derrota de Egipto en la guerra de 1967. En este sentido, el islamismo se perfilaba como una alternativa a una ideología fallida, cosa que se confirmó más tarde con la caída del muro de Berlín y con el retroceso de la oposición izquierdista en los países árabes e islámicos. Lo que aparecía como el auge del islamismo no pasaba de ser un vacío coyuntural malinterpretado tanto por los islamistas como por sus detractores. Sin programas políticos y económicos claros y con unos sólidos programas sociales, los islamistas siempre fueron percibidos como una fuerza para el cambio. Ante esta situación, las dictaduras árabes nunca perdieron de vista a los islamistas que sufrieron, en diferentes etapas, una dura represión.

Curiosamente, desde países occidentales democráticos se optó por una especie de análisis preventivo ${ }^{34}$ que supone que los partidos islamistas adoptan una aproximación utilitaria en lo que a la democracia se refiere, ya que fingen ${ }^{35}$ creer en los principios del juego político con el fin de llegar al poder, y destruir todos los elementos que integran el sistema del gobierno representativo, incluido el mecanismo de las elecciones que pueda brindarles la posibilidad de gobernar, según sus detractores ${ }^{36}$.

Este tipo de análisis tiende a evitar cualquier riesgo en detrimento de la propagación de la democracia y una de sus consecuencias es mantener y legitimar las dictaduras existentes en el mundo islámico en general y árabe en particular. En este sentido, cuando los resultados de las elecciones que ganó el Frente Islámico de Salvación (FIS) en Argelia fueron anulados en el marco del golpe de Estado protagonizado por el ejército politizado argelino, este era el argumento esgrimido. Desde la perspectiva de los países occidentales, en particular Francia, la antigua potencia colonizadora, esta actitud de complicidad con el poder en Argelia tenía que ver con el dilema del riesgo que supone dejar los islamistas gobernar el país o el apoyo a una dictadura

34. ALLUÉ BUIZA, Alfredo (2006): "Libertad y seguridad en Europa. La protección del pluralismo y las experiencias de democracia militante", in: Revista de Derecho de la Unión Europea. no 10 -1" semestre, pp. 235-255.

35. ZARROUK, Mourad ( 2005) : "El islamismo marroquí y la democracia", en Política Exterior, no 103, enero/febrero, pp. 129-138.

36. GONZÁLEZ SAMARANCH, Ricard (2009): “Democracia e islamismo ¿Un matrimonio imposible?", en: Revista CIDOB d'afers internacionals, no 84, pp. 181-200. 
supuestamente inofensiva en su política exterior. El mismo argumento fue utilizado en Argel, como si de una democracia anclada en la historia se tratara.

La comunidad internacional volvió a cometer el mismo error al gobierno de Hamas, que ganó las elecciones del año 2006, alejó en su momento las poblaciones árabes del sueño de la democratización de sus países. El argumento principal esgrimido para justificar el aislamiento de Hamas es el de su reciente pasado terrorista, como si la OLP de Yaser Arafat, con destacados miembros del movimiento Al Fatah y el Estado de Israel no hubieran perpetrado atentados terroristas en el pasado. Todas las facciones palestinas históricas, de corte islamista o izquierdista, además de Israel, tienen las manos manchadas de sangre de civiles. Por lo tanto, no había que sacrificar la democratización de la sociedad palestina para conseguir objetivos coyunturales.

En nombre del realismo político muchas dictaduras árabes fueron calificadas de "países árabes moderados" y su comportamiento es avalado por los países occidentales que no tienen en cuenta las aspiraciones de los pueblos oprimidos ${ }^{37}$. Lo cual suscita cierto rechazo a occidente por una parte y favorece la radicalización de algunos sectores de las sociedades árabes y musulmanas. La democracia aparente adoptada por dichos países llamados "moderados" ya no es suficiente para apaciguar los ánimos de las nuevas generaciones que han asistido al desgaste paulatino de los regímenes árabes, a pesar de que estos últimos se han empeñado en todo momento en desmarcarse de los modelos de dictaduras tradicionales en nombre de las especificidades locales y culturales.

Según Robert Dahl, "hasta los dictadores parecen creer en nuestros días que adoptar una o dos pinceladas de lenguaje democrático es un ingrediente imprescindible para su legitimidad" (Dahl, 2000: 10). Esta frase arroja luz sobre el titubeo de los regímenes árabes e islámicos desde la independencia, y explica el trasfondo de todo tipo de reformas introducidas en estos países; reformas que, claro está, no llevaron ninguna transición democrática como las experimentadas en la segunda parte del siglo XX en varios países.

La revalorización de la democracia como modelo de gobierno en el mundo arabo-musulmán empezó a notarse cuando una parte de las elites que lucharon por la independencia de los países árabes e islámicos se dieron cuenta de que la otra parte de las mismas elites se había hecho con el poder para perpetuarse en el mismo y no para edificar los nuevos Estados independientes. Fue el contexto de las constituciones otorgadas, de la llegada al poder de monarcas absolutos y del establecimiento de dictaduras militares. El contexto de la Guerra Fría permitió a

37. Se trata del realismo que no tiene en cuenta el derecho internacional o la organización internacional como mecanismo de orden, que distingue entre política interna y política exterior y que reconoce que las preocupaciones morales tienen sentido en la política interna, pero comparte la idea de que los principios universales de carácter moral no son aplicables a la acción de los Estados. Véase: MAGRHROORI, Ray y RAMBERG, Bennett (1982): Globalism versus Realism. International RelationsThird Debate, Boulder: Westview P. p. 223. 
estos regímenes justificarse en la sombra de los polos opuestos. Por lo tanto, cualquier proceso de democratización se consideraba como "algo que sobraba", pues la legitimación de la permanencia de los gobernantes árabes emanaba directamente de su "utilidad" en el delicado equilibrio de fuerzas.

Sin embargo, con la caída del muro de Berlín, el mundo se da cuenta, otra vez, de que las dictaduras habían fracasado ya a mediados del siglo XX. Las voces empezaron a alzarse para recordar que existían pueblos que vivían fuera del círculo de la democracia. En este contexto, los países árabes y musulmanes conocieron una serie de reformas mínimas que reflejaban la preocupación de los regímenes en el poder para presentar un modelo aceptable. En el caso de los países árabes, la década de los noventa conoció los dos primeros procesos electorales no manipulados: las elecciones legislativas en Argelia, que conocieron la victoria del Frente Islámico de Salvación FIS, y que fueron anuladas por el ejército argelino, y las elecciones en los territorios palestinos en 1996 que permitieron a Arafat convertirse en el primer jefe de Estado árabe elegido en unas elecciones libres y democráticas, aunque hay que tener en cuenta que Hamas, la principal formación de la oposición, decidió boicotear las elecciones.

Aparte de estas dos excepciones la década de los noventa conoció una serie de reformas constitucionales, promulgación de leyes de distinta índole, varios procesos electorales con resultados manipulados, mayorías aplastantes recortadas y elecciones presidenciales con un candidato único o con rivales de conveniencia.

A partir de los atentados del 11-S, los regímenes árabes, además del régimen paquistaní, recuperaron la utilidad perdida después de la caída del muro de Berlín. Algunos regímenes árabes cobraron de repente una considerable importancia a nivel regional e internacional gracias a su participación en la lucha contra el terrorismo, y a veces a su aceptación de la deslocalización de la tortura, admitiendo en sus cárceles secretas a reclusos con diferentes perfiles para someterlos a torturas en presencia de agentes estadounidenses ${ }^{38}$. Esta tenebrosa colaboración extrajudicial permitía a los regímenes que aceptaron participar en ese proceso protegerse contra las críticas internas y externas, por lo menos durante los siete años que duró la peculiar guerra de Bush contra el terrorismo.

Sin embargo, la era de Bush hijo no puede compararse con el largo periodo de la Guerra Fría. Las prácticas admitidas durante el desarrollo de la Guerra Fría, cuando con las credenciales de un bando u otro se podía legitimar cualquier comportamiento y cualquier forma de gobierno ya han quedado obsoletas. Pero a pesar de los progresos de la sociedad civil árabe, los regímenes árabes que se involucraron en la guerra contra el terrorismo intentaron durante la última

38. Comunicado de Human Rights Watch con fecha de 4 de noviembre de 2009. Véase: http://www.hrw.org/fr/news/ 2009/11/04/italie-tats-unis-un-tribunal-italien-condamne-la-pratique-de-redditions-extraordinai. Véase también Le Figaro del 27 de octubre de 2006. 
década utilizar el miedo de los países occidentales al terrorismo, a fin de legitimarse en el poder.

En cambio, las revoluciones que se han desencadenado en el mundo árabe ponen fin a esta etapa y vienen a demostrar que las aspiraciones de los pueblos van más allá de las iniciativas de apertura coyunturales de los regímenes árabes. Ya no se trata de reivindicar reformas, los jóvenes árabes reclaman el cambio de régimen ${ }^{39}$.

\subsubsection{La violencia genera violencia}

Sin lugar a dudas, los regímenes árabes e islámicos que han recurrido a la violencia para eliminar el islam político no son ajenos al recrudecimiento de la violencia. El hecho de haber excluido a los islamistas moderados del escenario político, recurriendo muy a menudo a métodos violentos, permitió a los elementos más radicales ganar el terreno paulatinamente y generó la radicalización de parte de las bases de partidos y asociaciones islamistas ${ }^{40}$. La eliminación de los islamistas como un actor político más del escenario político provocó un vacío que no fue colmado en ningún momento por organizaciones políticas conservadoras aunque, en algunos países, ciertos partidos nacionalistas intentan desempeñar este pape ${ }^{41}$. Ante esta situación, el discurso de los extremistas clandestinos avanzaba paulatinamente, incluso antes de la propagación de medios de comunicación modernos.

En este sentido, cabe recordar que la misma experiencia de radicalización se ha repetido prácticamente en todos los países donde los islamistas fueron objeto de persecución. Ningún país árabe o islámico ha sacado las conclusiones pertinentes de la experiencia de Egipto, que ya en los años cincuenta del siglo pasado vio cómo experimentaban algunos islamistas oprimidos la mutación al radicalismo y a la intransigencia. La aproximación descriptiva al proceso de radicalización de ciertos activistas de los Hermanos Musulmanes egipcios privó a los estudiosos del fenómeno islamista de un análisis estructural de este proceso. No era suficiente constatar que miembros destacados de los Hermanos Musulmanes como Sayed Qutb ${ }^{42}$ abandonaron paulatinamente la vía de la lucha política para adoptar un discurso intransigente acerca de las autoridades egipcias y, más tarde, acerca de la sociedad pagana. Había que situar este cambio en su contexto e intentar indagar en las razones del mismo.

39. Es el caso de los tunecinos, egipcios, yemeníes, sirios, libios e iraquíes. En otros países como Bahréin y Marruecos las reivindicaciones se centran en reformar la monarquía en ambos países.

40. Las escisiones de los Hermanos Musulmanes arriba mencionadas son un ejemplo acerca de la radicalización de una franja de la militancia de los partidos islamistas moderados.

41. En Marruecos, por ejemplo, el Partido del Istiqlal intentó desempeñar este papel gracias a que los líderes históricos del partido tenían una formación religiosa sólida y gracias también a las posiciones que tomó el partido en defensa del islam o de la política de arabización de la educación.

42. MAHFUZ, Mohammed (1988), op. cit., pp. 9-29. 
Mohammed Mahfuz describió las circunstancias en las cuales Sayed Qutb redactó su libro Ma'alem 'Ala Attariq (los hitos del camino). Aunque Qutb es el responsable del contenido de su texto, el régimen egipcio de aquel entonces había allanado el camino a la radicalización del islamismo en Egipto y preparado literalmente el caldo de cultivo de la violencia, reprimiendo a los islamistas moderados. El origen de la publicación del libro de Qutb remonta a una matanza de islamistas dentro de la cárcel egipcia de Turrah. Aquel $1^{\circ}$ de junio de 1956, sin previo aviso, las fuerzas egipcias irrumpieron en el penitenciario y abrieron fuego matando a 21 presos, entre los cuales figuraban varios dirigentes islamistas. Entre los que sobrevivieron a la matanza figuraba Sayd Qutb quien, acto seguido, calificó al régimen y a la sociedad de paganos.

Sayed Qutb era uno de los enfermos que fueron arrastrados de la enfermería de la cárcel para que fueran asesinados en la matanza. Fue cuando empezó a considerar que el régimen era "pagano" y que había que declararle la guerra aportando ejemplos de la fase anteislámica. Todos los indicios y los testimonios afirmaban que ese hombre afable y enfermizo juzgó de una manera cruel la sociedad conmocionado por los sucesos del 1 de junio de 1956. Fue apoyado por su discípulo y compañero de celda, el joven activista Mohammed Hawwash, que lo acompañó hasta el final, cuando los dos hombres fueron ahorcados en 1966 [...] La situación dentro del penitenciario era insoportable y supuso el punto de partida para que Qutb expusiera los pormenores de la condena al régimen pagano. Fue cuando fragmentos del borrador de su libro Ma'alem Ala Attariq (Los hitos del camino) empezaron a salir de la cárcel permitiendo así a los militantes que quedaban de los Hermanos Musulmanes manejar este texto en sus escondites y convertirlo en una guía durante aquella fase de desconcierto (Mahfuz, 1988: 26-27).

En esta fase, muy importante de la historia del islamismo en general, los islamistas más moderados sufrieron un desgaste irreparable. Incapaces de encontrar una salida política a la situación crítica de los militantes de los Hermanos Musulmanes, los despectivamente llamados hermanos constitucionalistas ${ }^{43}$ iban cediendo protagonismo a los elementos más exaltados que buscaban vengarse $^{44}$ del régimen y de las autoridades egipcias. Su discurso, dirigido a los sentimientos inmediatos de los egipcios en general y los islamistas en particular, tenía más eco que el discurso de los elementos moderados. La orientación revanchista, que no hay que olvidar que salió de la cárcel, contaba con más adeptos. Era la etapa de Sayed Qutb y del giro experimentado por algunos activistas de los Hermanos Musulmanes dentro de las cárceles egipcias.

43. Por hermanos constitucionalistas se entendían aquellos dirigentes de los Hermanos Musulmanes que seguían respetando las leyes y las instituciones a pesar del comportamiento violento del régimen hacia su organización. En su mayoría eran intelectuales, especialmente juristas, que pertenecían a la clase media y alta.

44. MAHFUZ, Mohammed (1988), op. cit., pp. 51-53. 
La regeneración de los Hermanos Musulmanes dejó de basarse en los presupuestos tradicionales de dicha organización, ya que el movimiento se identificaba con el violento texto de Sayed Qutb porque reflejaba su posición del régimen (Mahfuz, 1988: 35).

La aparición de movimientos en desacuerdo con los métodos pacíficos de los Hermanos Musulmanes en Egipto en los últimos 50 años no ha sido más que el resultado del comportamiento del régimen egipcio que se benefició, hasta cierto punto, de la radicalización del islamismo para justificar su política.

Lo que pasó en Argelia, después de la interrupción del proceso electoral por parte del ejército, fue el resultado directo de la neutralización definitiva del ala moderada del FIS. Una vez consumado el golpe de Estado, las bases de este partido empezaron a identificarse con los discursos poco moderados del número dos del partido, Ali Belhadj, antes de que el surgimiento del Grupo Islámico Armado (GIA) diezmara el partido debido al cambio de rumbo de algunos de sus militantes que se mostraron conformes con el alzamiento en armas y con la perpetración de atenta$\operatorname{dos}^{45}$. Los medios de comunicación ${ }^{46}$ internacionales, como la AFP, por ejemplo, resaltaban sobre todo las declaraciones de los elementos más exaltados del FIS durante la campaña electoral. Son inolvidables, de hecho, las palabras que pronunció Hachemi Sahnouni el 8 de mayo de 1991 cuando prometió suspender la Constitución, prohibir los partidos laicos, aplicar la sharia y expulsar al presidente de la República; o las del sheij Moghni, que pretendía crear tribunales populares para juzgar a los "heréticos y enemigos del pueblo" (Thieux, 2007: 70-71). Dicho esto, hay que tener en cuenta también que muchos discursos fueron manipulados por los medios de comunicación en aquel contexto (Thieux, 2007: 71).

Tanto el FIS como el GIA estaban infiltrados por la ex Seguridad Militar argelina, que pasó a ser le Département du Renseignement et de la Sécurité DRS que orquestó indirectamente entre mayo y junio de 1991 la trágica huelga que originó el golpe de Estado. Después de la creación del GIA, en diciembre de 1992, el DRS empezó a atribuir sistemáticamente terribles matanzas a este grupo (Géze, 2005 y Samraoui, 2003). Pero esto no quiere decir que la represión no haya contribuido en la radicalización de los militantes del FIS y abierto el camino a los "argelinos afganos" a apoderarse de la cúpula del GIA. La represión del ala moderada del FIS y la radicalización del islamismo sumergieron el país en el caos. El terror ya se había establecido en la zona después de la exclusión del FIS del escenario político argelino. La aparición, más tarde, del Grupo Salafista para la Predicación y el Combate, convertido en la rama magrebí de la

45. Sobre los atentados del GIA, véase el libro del oficial argelino Habib SOUAIDIA: SOUAIDIA, Habib (2001): La sale Guerre, Paris: La Découverte y YOUS, Nasroulah (2000): Qui a tué à Bentalha?: chronique d'un massacre annoncé, Paris: La Découverte.

46. Abed CHAREF (1994): Algérie, le grand dérapage, La Tour d'Aigues : L’Aube, p. 130.

ORÍGENES DEL TERRORISMO GLOBAL: UNA PROPUESTA DE ANÁLISIS 
organización Al Qaeda; Al Qaeda en el Magreb Islámico ${ }^{47}$ fue el desenlace lógico de la intervención del ejército en la vida política y del apoyo de los países occidentales, en nombre de la realpolitik, al continuismo en Argelia.

En Marruecos se ha hablado tanto de la "excepción marroquí" antes del 16 de mayo de 2003, que nadie se ha dignado en analizar los fundamentos de esta situación que tenía que ver con la ficción más que con cualquier otra cosa. Por la desvanecida "excepción marroquí" se entendía el carácter inmune de este país magrebí contra la violencia. De hecho, antes de los atentados de Casablanca, 16 de mayo de 2003, no había antecedentes de violencia yihadista, si exceptuamos el misterioso atentado de Marraquech, 1994, que cobró la vida de dos turistas españoles. Se trata de un atentado supuestamente perpetrado por franceses de origen marroquí y argelino que Marruecos acusó de llevar a cabo una operación ideada por los servicios de inteligencia argelinos, a pesar de que los cuerpos de seguridad franceses y el juez de instrucción Jean-Louis Bruguières hayan relacionado este grupo con redes "islamistas" en Francia ${ }^{48}$.

Este atentado acarreó graves consecuencias políticas, especialmente a nivel de las relaciones bilaterales entre Marruecos y Argelia. De hecho, las fronteras entre los dos países permanecen cerradas desde aquel entonces. Sin embrago, Marruecos no perdió su "estatuto" de país estable y de oasis de moderación en comparación con el resto de los países árabes. Este mito se vio alimentado por la ausencia de cualquier comportamiento violento por parte de los islamistas marroquíes, desde el asesinato del militante socialista Omar Benjelloun por miembros de la Shabiba Islamiya (Juventud Islámica) en 1975. La Shabida Islamiya, grupo creado en 1969, se desmembró paulatinamente. Más tarde, en junio de 1996, los islamistas de la asociación Reforma y Renovación, entre los cuales figuraban exmiembros de la Shabida Islamiya, pasaron a formar parte de un modesto partido político creado en 1966 por Abdelkrin el Jatib: el Movimiento Popular Constitucional Democrático MPCD. El régimen marroquí consiguió en aquel entonces llevar los islamistas al Parlamento, no en tanto que miembros de un partido islamista, sino como individuos que aceptaron trabajar desde una organización política no islamista (el MPCD) que más tarde se convertiría en el Partido de Justicia y Desarrollo (PJD) (Zarrouk: 2005).

La otra formación islamista con una amplia base en la sociedad marroquí, Al Adl wal Ihsan (Justicia y Espiritualidad), permaneció fuera del escenario político sin amenazar, por lo tanto, en ningún momento la seguridad de Marruecos (Zarrouk, 2005). ¿Era suficiente esta situación para

47. El 24 de enero de 2007, Abdulmalek Droukdal, alias Abu Musa'ab Abdulwadud, jefe del Grupo Salafista para la Predicación y el Combate, anuncia el cambio del nombre de la organización que pasa a ser Al Qaeda en el Magreb islámico, dependiendo más ideológicamente que organizativamente de la organización madre.

48. Libération del 10 de enero de 1995. 
pensar que Marruecos representaba una excepción? Los que no querían ver la pura realidad se agarraron al mito de la "excepción". Sin embargo, todas las condiciones de radicalización de elementos islamistas y de salafíes apolíticos estaban reunidas, especialmente la invisibilidad de los islamistas marroquíes y el mantenimiento de una política que tendía a ignorar un actor político dinámico, como era el caso de los islamistas de Al Adl wal Ihsan y los del PJD, en un espacio en el cual los partidos políticos marroquíes estaban cuestionados, sobre todo después del fracaso de la experiencia de la alternancia.

A partir de los atentados del 11-S estaba muy claro que el mantenimiento del statu quo, en lo que al islamismo marroquí se refiere, era muy difícil. El régimen marroquí cometió el error de pensar que no iba a haber más actores en el ámbito del islam político. El PJD ya estaba dentro del parlamento, y sus miembros ya habían roto con el aventurismo de la shabiba islamiya. Al Adl wal Ihsan, que no recurrió nunca a la violencia, mantenía un discurso duro e intransigente hacia la monarquía sin modificar su estrategia. El resto de los grupos y asociaciones islamistas eran minoritarios e insignificantes. Sin embrago, esta situación cambió cuando se conoció que hubo marroquíes que pasaron por los campos de entrenamiento en Afganistán y que otros participaron más tarde en operaciones contra las fuerzas norteamericanas en Irak $^{49}$. Por otra parte, las operaciones policiales realizadas en diferentes países europeos dejó claro que había muchos marroquíes que integraban células allegadas a la organización de Al Qaeda en el viejo continente ${ }^{50}$. A esta nueva realidad hay que añadir que el discurso de los islamistas no penetra con facilidad en el mundo rural y, mucho menos, en los poblados y los barrios marginales de las grandes ciudades de donde salió el comando que perpetró los sangrientos atentados del 16 de mayo de 2003 y el resto de los atentados frustrados en Casablanca. Se puede decir que antes del 16 de mayo de 2003, el mapa del radicalismo marroquí estaba configurado.

Los atentados de Casablanca vinieron a demostrar que la política de contención del islamismo moderado no era adecuada porque creó el vacío aprovechado, más tarde, por el radicalismo violento. El régimen marroquí no contribuyó tampoco en la creación de una dinámica de integración de todos los islamistas que rechazaban la violencia de tal manera que el discurso islamista moderado sustituyera cualquier otra alternativa. Marruecos no rentabilizó bien los errores cometidos anteriormente por el régimen egipcio y argelino para evitar la radicalización de los elementos que pasaron a nutrir las filas de los grupos violentos.

49. El Grupo Islámico Combatiente Marroquí, que contaba con su propio campamento en Afganistán, empezó a llamar la atención debido a sus vínculos con Al Qaeda. Este grupo fue considerado parte del terrorismo internacional en la resolución 1267 del Consejo de Seguridad de la ONU.

50. JORDÁN, Javier (2005):"El terrorismo islamista en España", in: Amalio Blanco, Rafael del Águila y José Manuel Sabucedo (Eds.): Madrid 11-m. un análisis del mal y de sus consecuencias, Madrid: Trotta, p. 82. 


\section{LOS FRACASOS LETALES}

\subsection{Los "ulemas de Palacio" y las limitaciones del islam oficial}

Este concepto, despectivo por cierto, es tan antiguo como los mismos ulemas o alfaquíes. Por "ulemas de Palacio" se entiende aquel grupo de jurisconsultos musulmanes cortesanos legitimistas que ponían su conocimiento al servicio del poder político, especialmente el gobernante. No se trata de un concepto preciso, pues por el mismo se intenta por parte de otro grupo de alfaquíes subversivos o, sencillamente, por parte de los musulmanes de a pie desacreditar a los ulemas allegados al poder político.

Al catalogar algunos tratadistas musulmanes como alfaquíes cortesanos, no pretendemos pronunciarnos de una manera definitiva sobre sus preferencias ideológicas o sus inclinaciones políticas. El repaso del pensamiento político en el ámbito islámico deja claro que no existen ideas bien ancladas en la teoría política ni tampoco en los textos religiosos. Son más bien posturas tomadas en función del contexto. La práctica fue mucho más decisiva en lo que se refiere a las posiciones políticas de los exégetas de los textos sagrados.

Los alfaquíes que respaldaban el poder político de una manera incondicional, adoptando interpretaciones justificativas ${ }^{51}$, no diferían mucho de los teólogos cristianos que pusieron sus conocimientos al servicio de los gobernantes que tenían ciertas afinidades ideológicas con la Iglesia Católica. Esta categoría de alfaquíes pensaba que el hecho de apoyar un gobernante determinado o un régimen en especial podía servir a la causa de una creencia y de unos preceptos determinados. Los resultados inmediatos pueden ser satisfactorios, pero este tipo de posiciones suele erosionar la legitimidad de quien asienta las bases morales de los regímenes totalitarios.

Las razones de la legitimación del poder político o de la actuación de un gobernante por parte de un alfaquí no suelen responder siempre a las mismas razones. Muchas veces, la obsesión por la seguridad de la comunidad que tenían algunos alfaquíes les convertía en instrumentos de propaganda a favor de la estabilidad de un régimen determinado. En otras palabras, los ulemas no disfrutaban siempre de ventajas en contrapartida de sus opiniones dormitivas. Para evitar el demasiado temido caos político y social, la comunidad, c en la única parte responsable de la seguridad colectiva, tiene que obedecer ciegamente al gobernante, como si a este último no le incumbiese velar por la estabilidad del espacio que gobierna.

51. Se trata de aquellos alfaquíes y ulemas descritos despectivamente como "ulemas del sultán" o de "palacio". Aunque este tipo de ulemas estaba en todas las cortes donde se necesitaba una legitimación religiosa de los actos del gobernante, hay que reconocer que no se trata de una categoría bien definida, pues "frecuentar" el gobernante es suficiente para que el ulema perdiera credibilidad ante los fieles porque se supone que la imparcialidad y hasta la integridad del ulema se compromete debido a la relación con el gobernante, lo cual es corroborado por dichos del profeta, como: "los ulemas velarán por la misión de los profetas ante la gente mientras no frecuenten los gobernantes, y si los frecuentan habrán traicionado a los profetas. iNo os fiéis de ellos, iAlejaos de ellos!" 
En este sentido, cabe resaltar las opiniones del juez de Bagdad Abû Yûsuf (731-782), amigo del califa abbasí Harûn ar-Rashîd, Abu Al Hassan Al Mâwardî (972-1058) e Ibn Hazm de Córdoba (994-1064), conocido por su apoyo incondicional a los omeyas, entre otros ulemas. Al contemplar las consecuencias de las opiniones de estos jurisconsultos musulmanes, se puede deducir que fueron víctimas de una visión idealista del concepto del poder ${ }^{52}$. Imaginar una relación vaciada de matices entre los gobernados, obedientes por definición, y los gobernantes piadosos y justos fue quizás el elemento más nocivo que originó un vacío a nivel del iytihad (esfuerzo interpretativo) para referirse a casos de poder corrupto. Los "ulemas de Palacio" participan también en la gestión del campo religioso desde la perspectiva del islam oficial. En algunos países como Arabia Saudí, la alianza entre la familia real y el "clero" ultraconservador es algo más que estratégica. El régimen político garantiza a los ulemas toda la libertad necesaria para llevar a la práctica la doctrina decimonona de Mohammed Ibn Abdelwahhab y los preceptos, no declarados, de la jurisprudencia según el rito de Ahmed Ibn Hanbal, e incluso contribuye en la exportación de la misma al resto de los países islámicos y a las minorías musulmanas en Occidente. En contrapartida, los ulemas saudíes defienden a capa y espada la legitimidad del régimen político y advierten a los fieles de lo nefasto que sería cualquier cambio político forzado ${ }^{53}$.

La instrumentalización de la religión no es un rasgo característico del régimen saudí. Países como Egipto, Siria, Túnez o Marruecos tienen una larga experiencia en lo que se refiere a la colaboración con los alfaquíes para contrarrestar la labor de los islamistas como actores que tienen unos presupuestos ideológicos basados en la religión ${ }^{54}$.

En Egipto, la larga subordinación de los ulemas de la Universidad de Al Azhar acabó desgastando la figura y la legitimidad de esta institución. Tanto el Muftí de la República como Sheikh Al Azhar o el Ministro del Awqaf (bienes del habús) se dedicaron a partir de los últimos años del régimen de Anuar Sadat a preservar la legitimidad del presidente avalando, desde el punto de vista religioso, sus decisiones políticas. En este sentido, cabe recordar la labor realizada por Yad al-Haqq Alí Yad al-Haqq durante los momentos más difíciles de la trayectoria política del

52. Esta visión coincide con el planteamiento kantiano: "el origen del poder supremo es inescrutable, bajo el punto de vista práctico, para el pueblo que está sometido a él; es decir, que el súbdito no debe razonar prácticamente sobre este origen, como un derecho controvertido con respecto a la obediencia que le debe. Porque, puesto que el pueblo, para juzgar valederamente del poder soberano de un Estado, debe ya ser considerado como reunido bajo una voluntad legislativa universal, no puede ni debe juzgar de otra manera más que como agrade al poder soberano existente. Véase: KANT, Emmanuel (1978): Principios metafísicos de la doctrina del Derecho, Méjico: Universidad Nacional Autónoma de Méjico, p. 149.

53. De hecho, suelen repetir en los sermones y en sus publicaciones que hasta que el gobernante no prohíba la oración, está prohibido derrocarle. Véase. ABDELLAH, Anuar (2004): Al ulam'a wal a'arch: zunaiyat assultah fi Assu'diyah, Beirut: Dar al buraq.

54. Darif, Mohammed (1999) Al-islamiyyun al-magariba, publicaciones de la revista marroquí de sociología política, Casablanca: Annajah. 
presidente egipcio Sadat. Yad al-Haqq emitió una fatwa ${ }^{55}$ que respaldaba los acuerdos de paz con Israel, concluidos en 1978, y otra igual que legitimaba la promulgación de la polémica ley de la familia (Arigita, 2005: 149-150). Sin embargo, la designación de Mohammed Sayed Tantawi como Sheij Al Azhar, a partir de 1996, marcó el inicio de una vertiginosa decadencia de esta institución, pues a diferencia de sus predecesores, no mantuvo ningún tipo de distancia con el poder que le utilizaba cada vez que lo estimaba oportuno.

El resultado lógico de esta situación es la desacreditación total de la exprestigiosa institución de Al Azhar. Hay que recordar que desde la designación de Mohammed Sayed Tantawi, este último procuró, antes de su fallecimiento en Arabia Saudí, neutralizar una asociación que obraba desde la universidad de Al Azhar. Se trata de una asociación que se llama el Frente de los Ulemas de Al Azhar (Yabhat U'lama'a Al Azhar), que había sido creada en 1946. La decisión de un tribunal egipcio en 1999 de suspender las actividades de esta asociación fue una manera también de intentar evitar la labor subversiva de este grupo. Este frente está hostigando Al Azhar desde su página web creada en Kuwait, a fin de devolver Al Azhar a su gente, tal y como declaró uno de los ulemas de esta institución que forman esta especie de oposición virtual al legitimismo de esta institución ${ }^{56}$.

En Marruecos, el monarca es al mismo tiempo emir de los creyentes $^{57}$. Este título genera una de las mayores confusiones en el ordenamiento jurídico marroquí, debido a que pretende darle una dimensión sagrada a un cargo que se transmite de padre a hijo y que garantiza al monarca que, obviamente, reina y gobierna un impresionante arsenal de atribuciones sin que ningún otro actor político pueda cuestionar la labor del rey o pedir responsabilidades. Consciente de la importancia de la religión como un componente de legitimidad, Hassan II no descuidó en ningún momento la gestión del campo religioso.

Así pues, se puede decir que la base del islam oficial en Marruecos es el carácter casi obligatorio del rito malekí, pues la unificación del trasfondo religioso de toda una nación facilita el control

55. Dictamen jurídico emitido por alfaquíes o ulemas musulmanes. Las fatwas no son vinculantes en el Islam hasta que se produzca Al iymâ' (unanimidad), lo que quiere decir que muy pocos dictámenes son vinculantes para los fieles.

56. Declaración de Yahya Ismael Hablush al periódico Ashark al Awsat con fecha del 5 de agosto de 2008.

57. Aunque se ha consagrado en el imaginario de muchos musulmanes que emir de los creyentes es un concepto islámiCo, en realidad se trata de un expresión acuñada por el segundo califa Omar Ibnu Al Jattab, al fin de evitar la redundancia de la expresión siguiente: jalifatu jalifati rasuli Allah (el sucesor del sucesor del enviado de Dios). Ni emir de los creyentes ni jalifa o califa (sucesor) son cargos establecidos por el Corán o el hadiz. Los textos sagrados del islam no regularon ni la sucesión en el poder ni el tipo de cargo del gobernante (califa, rey o emir...). En los tratados de los jurisconsultos musulmanes encontramos muy a menudo el término imâm. Sin embargo, Esta voz designa al mismo tiempo la persona que dirige las oraciones y también la que dirige toda la comunidad. El sentido se entiende a la luz del contexto del texto o del discurso. Cuando se utiliza el sustantivo -que se transcribe, ora imâma, ora imâmato- se le añade el adjetivo sugrà (menor) para designar la dirección de las oraciones o 'uzmâ (mayor) que quiere decir la dirección de la comunidad. Algunos ulemas ortodoxos, como Ibn Taymiyyah, llegaron a decir que la umma no necesitaba forzosamente un califa. Véase IBN TAYMIYYAH (2003). 
del campo religioso. En este sentido, Hassan II no tuvo ningún problema en rentabilizar la hegemonía de esta escuela jurídica del islam suní. Cabe recordar en este sentido sus palabras, muy significativas a este respecto:

Queremos un Marruecos unificado en su moral y su comportamiento por la lengua, la religión y el rito. Nuestra religión es el Corán y el islam, nuestra lengua es la del Corán y nuestro rito es el del imam Malek ${ }^{58}$.

Otra dimensión de la organización minuciosa del ámbito del islam oficial en Marruecos es la institucional. Pero en este sentido hay que resaltar la importancia del contexto de la jerarquización y el robustecimiento del islam oficial. Se trata de una serie de pasos calculados dados por Hassan II en los años sesenta creando Dar Al Hadiz Al Hasania (1964), la Asociación de los Ulemas de Dar Al Hadiz (1967) y más tarde el consentimiento de la creación de la Rábita (liga) de ulemas marroquíes (1969). El contexto de los años sesenta era peculiar debido al auge que conoció el panarabismo naserista a pesar de la derrota en la Guerra de 1967. La proyección del naserismo fuera de Egipto amenazaba directamente las monarquías árabes. De hecho, el régimen marroquí estaba preocupado por la alianza entre Egipto y Argelia después de la llegada de Bumedian al poder en 1965 y por el giro de Libia hacia el panarabismo después del golpe de Estado llevado a cabo por Gaddafi en 1969. La monarquía marroquí tenía otro rival en el interior, la extrema izquierda. Es lo que le explica la opción de utilizar un islam oficial legitimista a partir de ese momento, además de consentir tácitamente el nacimiento de la Shabiba islamiya (Juventud Islámica) en 1969.

El nacimiento de la Juventud Islámica en Marruecos servía directamente los intereses de la monarquía en su búsqueda de un difícil equilibrio regional, pero también en su lucha contra la izquierda revolucionaria marroquí. El régimen de Hassan II descubrió la comodidad de ceder un litigio ideológico a la Juventud Islámica que se caracterizaba por la violencia de su procedimiento, un carácter no tan ajeno a la radicalización de todos los actores políticos de la época, incluida la monarquía. Por otra parte, la lucha directa entre el régimen y la izquierda acarreó una serie de problemas a las autoridades marroquíes, sobre todo después del asesinato del líder izquierdista, Mehdi Ben Barka, en París, en 1965. Diez años más tarde, siete militantes de la Shabiba asesinaron al socialista Omar Benjelloun. El régimen de Hassan II se deshizo de un opositor tenaz sin implicarse directamente en el asesinato.

El régimen marroquí alternaba la utilización de la Juventud Islámica como instrumento de carácter religioso con otro instrumento, más bien de carácter institucional. Es el contexto en el cual podemos situar la creación de Dar al Hadiz Al Hasaniya, un centro especializado en la formación de ulemas encargados de custodiar la legitimidad religiosa de la monarquía.

58. Discurso pronunciado por Hassan II en el Congreso de los Diputados en octubre de 1970.

ORÍGENES DEL TERRORISMO GLOBAL: UNA PROPUESTA DE ANÁLISIS 
Este centro, creado en 1964, coincidió con la llegada de varios militantes islamistas que huyeron de Egipto y Siria ante la represión que sufrió el movimiento de los Hermanos Musulmanes en estos dos países. El 28 de junio de 1967 fue creada la citada Asociación de Ulemas de Dar Al Hadiz Al Hasaniya, integrada por antiguos alumnos de este centro religioso. La asociación mantenía estrechas relaciones con otras de corte islamista. Los papeles de los distintos actores se complementaban en el marco de una armonía garantizada por la existencia de un enemigo común, la izquierda radical, y sobre todo por el visto bueno del régimen al que le convenía la armonización de los esfuerzos de dichos actores para frenar el avance de los extremo-izquierdistas ${ }^{59}$.

A diferencia de la crispación que sufre actualmente la relación entre los ulemas oficiales y los militantes islamistas, la desigualdad entre el ulema y el islamista era ambigua porque se confundían las dos figuras. Por ejemplo, el líder nacionalista Allal El Fasi, uno los ulemas más conocidos en Marruecos, difundió las ideas de Sayed Qutb reimprimiendo sus libros en la imprenta Arrisala, propiedad del partido Istiqlal ${ }^{60}$.

A través del Ministerio del Awqaf, de Dar Al Hadiz Al Hasaniya, de la Asociación de los Ulemas de Dar Al Hadiz, de la Liga de los Ulemas, que después de la época de Abdellah Guennoun perdió su autonomía (Tozy, 2000: 98), y a través de los consejos regionales y de todas las mezquitas del país completamente sometidas, el régimen de Hassan II consiguió acaparar todo lo que tenía que ver con el islam en Marruecos. Salvo el margen insignificante que ocupaban discursos marginales como el de los islamistas de diferentes asociaciones, sobe todo Al Islah wa Attajdid y Al Adl wal Ihsan y los salafíes tradicionales, el islam del majzén estaba presente en todos los espacios. Sin embrago, ni Marruecos ni el resto de los países árabes tuvieron en cuenta el peligro de desvirtuar e instrumentalizar la religión y los ulemas. De hecho, con el paso del tiempo el discurso del islam oficial ya estaba completamente desfasado.

En resumidas cuentas, el discurso que se genera dentro del islam oficial suele tener una vida muy corta y los ulemas que participan en la gestión del campo religioso desde una perspectiva oficialista acaban pagando la gestión de su propia reputación debido al desgaste que sufren paulatinamente durante su alianza con los gobernantes que, en el imaginario de amplios sectores de la sociedad, son déspotas que mantienen una relación utilitaria con el islam. Cabe recordar en este sentido lo que pasó en Arabia Saudí después de la segunda Guerra del Golfo en 1991. Las limitaciones del islam oficial, que encarna esta relación sin fisuras entre el poder político y los ulemas, dieron lugar al rechazo manifiesto de las interpretaciones legitimistas de los ulemas a partir de dicho conflicto, cuando los ulemas más destacados del país justificaron el uso

59. Darif, Mohammed (1999) Al-islamiyyun al-magariba, publicaciones de la revista marroquí de sociología política, Casablanca: Annajah.

60. Darif, Mohammed (1999) Al-islamiyyun al-magariba, publicaciones de la revista marroquí de sociología política, Casablanca: Annajah. 
por parte de las fuerzas internacionales del suelo saudí, a fin de atacar las fuerzas iraquíes en Irak y Kuwait ${ }^{61}$.

En lo que se refiere a las instituciones, y teniendo en cuenta que en el islam no existe el concepto de institución religiosa, es difícil que una estructura jerarquizada tenga el mismo valor que tuvo Al Azhar en Egipto, Azzaituna en Túnez o Al Qarawiyyín en Marruecos. Se trata, en esos tres casos, de una reputación forjada a través de siglos de formación de ulemas independientes y de investigación en las diferentes ramas de estudios islámicos. Este poder social, construido a través de siglos de trabajo, disminuyó rápidamente en los tres países árabes en cuestión de años. Dicho esto, no podemos comparar la relación entre Sadat, y más tarde Mubarak y el sheij del Al Azhar, con la labor de domesticación de Az zaituna y de Al qarawiyyín durante, respectivamente, la era de Habib Burguiba en Túnez y la de Hassan II en Marruecos, debido al peso y al papel político religioso de Al Azhar. Las bases de estas instituciones fueron socavadas justo cuando se estaba gestando un pensamiento violento que se aprovechó del vacío dejado por la ausencia de ulemas competentes y autónomos capaces de contrarrestarlo.

\subsection{El agotamiento de las corrientes islamitas}

Sería oportuno hoy en día preguntarnos por las consecuencias de la probable extinción de las corrientes islamistas ${ }^{62}$. A primera vista se puede pensar que la desaparición de los islamistas no cambiaría nada en el escenario político de los países árabes e islámicos. El desconocimiento de la realidad religiosa, política y social de los países árabes, sobre todo, llevaría a los rivales del islam político a desear tal desenlace. Sin embargo, basta con analizar el resultado del declive del islamismo, que precedería quizás a una caída definitiva del mismo, para constatar cómo los radicales han ocupado rápidamente el terreno abandonado por los islamistas en Egipto y en Argelia, por ejemplo.

La marginación y represión de los islamistas en algunos países árabes e islámicos es una de las causas, quizás la principal, pero no la única. El apoyo de países occidentales a las dictaduras árabes es otra causa ${ }^{63}$. Pero también hay factores internos dentro de los partidos islamistas árabes que explican la crisis que viven.

61. Dictamen del entonces muftí de Arabia Saudí, Abdulaziz Ibn Baz, publicado en el periódico Al-Jazirah, con fecha 17 de agosto de 1990.

62. Por islamistas entendemos siempre aquellas corrientes que se sitúan dentro del islam político, excluyendo de esta definición los yihadistas y los salafíes tradicionales.

63. Ya hemos comentado algunas razones relativas a tal connivencia, especialmente las que tienen que ver con el miedo a la llegada de los islamistas al poder y el supuesto peligro que estos representarían de cara a la preservación de la seguridad de los países occidentales. Pero también hay razones económicas; en este sentido, un exagente de la CIA se refirió en su libro, anónimo al principio, (SCHEUER, 2004) a la falta de alternativa de los norteamericanos en lo que se refiere a la consecución del petróleo a un buen precio, lo que les llevó a proteger las dictaduras árabes de los países del Golfo Pérsico contra la voluntad de Ben Laden y otros. 


\subsubsection{Agotamiento político}

El agotamiento de las corrientes islamistas se refleja en la pérdida de popularidad de partidos que no han llegado a gobernar. Independientemente de la manipulación de los recortes del mapa electoral o de los resultados de las elecciones, se nota que hay un retroceso palpable de los movimientos islamistas tolerados. Antes del inicio de las revoluciones árabes, en Egipto los Hermanos Musulmanes ya no se perfilaban como la alternativa al partido del derrocado Mubarak. En Túnez el partido de Rashed Al Gannouchi, An-Nahda, se había convertido en una organización política invertebrada cuyos líderes estaban fuera del país. Los sudaneses vieron cómo los islamistas entraron en batallas dialécticas para explicar la escisión y el divorcio dramático entre Omar Al Basher y su ideólogo Hasan Atturabi. Más dramático fue el desenlace de la primera guerra de Afganistán que supuso, durante la lucha de los muyahidines contra el Ejército Rojo, un gran apoyo a todos los movimientos islamistas. En Marruecos, el fracaso electoral del PJD en las elecciones legislativas de 2007 y en las municipales de 2009 es una prueba de que el tiempo no ha sido nunca el mejor aliado de los islamistas. El PJD se estrenó en algunos municipios y su gestión fue bastante buena, igual que su comportamiento como actor político en la oposición, pero aún así fue castigado por el electorado que, por mucho que pueda comprender las presiones ejercidas sobre el partido, no esperará más tiempo para que los islamistas aprendan a hacer el balance oportuno de su participación en el juego político. Los cambios que están sucediendo en los países árabes pueden ser una ocasión propicia para integrar definitivamente a los partidos islamistas en un escenario político saneado.

Esta serie de fracasos se debe a factores externos relativos al comportamiento de otros actores políticos, pero se debe también a errores cometidos por los mismos islamistas que ya no tienen la fuerza necesaria para procurar más legitimidad que los grupos violentos que actúan en el nombre del islam. Dicho esto, hay un problema estructural dentro del islamismo. Se trata aquí de los problemas derivados de las interpretaciones aportadas por los islamistas para romper con las interpretaciones tradicionales, que supuestamente carecen de capacidad de movilización, tanto en el islam sunní mayoritario como en el shií ${ }^{64}$.

Si nos centramos en los islamistas que obran desde el islam sunní mayoritario, nos encontraremos con problemas de exégesis mal contextualizadas de los textos sagrados del islam. Estos errores tarde o temprano iban a poner en evidencia el discurso islamista. La hermenéutica islamista también tiene la vida muy corta.

\subsubsection{La hermenéutica islamista}

Por hermenéutica islamista no entendemos ninguna especialidad de estudios islámicos ni ninguna orden apartadiza en el mundo islámico. Aquí nos referimos a la adaptación de los textos para

64. No hay que olvidar que la revolución iraní se basó esencialmente en la teoría, no contextualizada, de wilayat al faqih rescatada literalmente por Jomeini de la obra de Ahmed Ennuraqui: A'awa'idu Al ayyam, publicada en el año 1830. 
justificar o apoyar las posturas políticas de los islamistas. Nos referimos a lecturas actualizadoras, que en varias ocasiones dejan de lado el mensaje original para deslizar otra interpretación que corresponde a una coyuntura determinada. Este procedimiento privó a los mismos islamistas de la comodidad de referirse a un sistema de valores islámico en general, sin entrar en detalles que no tienen cabida en los textos esgrimidos. Un sistema de valores que pueden utilizar como trasfondo en todos los asuntos políticos, pero sin pretender que se refiere de una manera pormenorizada a todos y a cada uno de estos asuntos.

El hecho de que existan aleyas y dichos del Profeta que se refieren expresamente a la política, no quiere decir que cualquier persona que se identifica con los valores del islam esté capacitada para erigirse como exegeta y mucho menos cuando se trata de intelectuales conservadores que, como San Jerónimo, cuando emprendió la traducción de la Biblia, creen también que existe una especie de "inspiración divina" que les permite llevar a cabo un ejercicio de hermenéutica aplicada a los diferentes escenarios políticos en los países árabes e islámicos. No se trata tampoco de defender a ultranza un contextualismo inamovible y llevar hasta la última de las consecuencias la necesidad de leer algunos textos sagrados del islam en su contexto correspondiente, ni se trata de una exclusión automática de las "verdades atemporales" para centrarnos en el contexto que rodeó el nacimiento del texto en cuestión. Claro que muchas moralejas coránicas pretenden perdurar después del desenlace de las historias que les corresponden: el denigrado absolutismo del Faraón frente al reparto de la misión profética entre Moisés y Arón, por ejemplo, o el concepto de la šūàa ${ }^{65}$. No obstante, el contexto preciso de los textos es necesario para la comprensión y análisis de los mismos antes de proyectarlos en otra realidad. De ahí el problema que plantean las interpretaciones propuestas por algunos islamistas.

El problema esencial de estas interpretaciones no consiste en mezclar los preceptos de la religión con la política, como suelen repetir muy a menudo los críticos de esta categoría de políticos, sean rivales políticos a nivel local o estudiosos de países occidentales que parten de su propia realidad para opinar sobre el mundo árabe e islámico ${ }^{66}$. Es una aseveración que tiene todo el morbo del simplismo. En su afán de rentabilizar los resultados de las memorables luchas para separar la iglesia del Estado en los países occidentales, los rivales del islamismo suelen utilizar los mismos argumentos que permitieron la neutralización del clero politizado en el contexto cristiano sin tener en cuenta la realidad del mundo musulmán. Es una realidad que se basa en una serie de rasgos característicos como, por ejemplo, la inexistencia de una institución religiosa o

65. Los etimólogos árabes afirman que el origen de la voz šūrà, sustantivo en femenino, procede del verbo šara, que quiere decir extraer la miel de los panales. De ahí el sentido figurado del concepto coránico šūrà. La šūrà es el hecho de debatir una idea y consultar varias personas antes de optar por una decisión determinada basada en el consenso.

66. Se utiliza también la fórmula, no menos ambigua, de politizar el islam. Véase: IZQUIERDO BRICHS, Ferrán y FARRÉS FERNÁNDEZ, Guillem (2008): "La competición por el poder político entre el islam político y los militares en Turquía", in: REIM, no 5, pp. 109-132. 
de una autoridad similar. Por lo tanto, el debate sobre el laicismo tiene que centrarse en la conveniencia o no de tener un trasfondo religioso a la hora de dedicarse a la política.

El problema de estas interpretaciones sería, sobre todo, la tendencia normativista que atribuyeron al texto coránico, defendiendo la existencia de unas pretensiones organizativas que este texto no llegó a albergar en ningún momento. La esquematización de principios y recomendaciones de carácter político fue principalmente una iniciativa de los islamistas que, en vez de inspirarse en estas ideas aprovechando el margen de creatividad dejado por los textos, se dejaron llevar por una lectura normativista y jerarquizante ${ }^{67}$ que restringe en gran parte los esfuerzos que tienden a inspirarse de otras experiencias ajenas al ámbito islámico o a indagar en senderos inexplorados dentro de la historia del islam.

La complejidad de esta situación se ve más acentuada cuando tenemos en cuenta que esta lectura normativista cambia de una experiencia a otra, de la misma manera que los musulmanes del mundo no interpretan de la misma forma los textos sagrados del islam. Por lo tanto, hay un solo islam, un solo texto, varias escuelas jurídicas, adaptaciones diferentes de la religión a la práctica, muchas culturas de recepción y muchos grupos que se identifican cada uno a su manera con esta cultura y, por consiguiente, ofrece una lectura diferente a la de los demás. Los impulsos normativistas de los islamistas fueron un error que tarde o temprano iba a perjudicarles por muy vertiginoso que fuera su ascenso después de la caída del panarabismo.

\section{CONCLUSIONES}

Se necesitará seguramente mucho tiempo y cambios profundos en el mundo árabe e islámico y también en el comportamiento de los países occidentales para que se cierre este ciclo de violencia; sin embargo, podemos proponer las conclusiones siguientes para cerrar esta propuesta de análisis.

- Los resultados de la primera Guerra de Afganistán invitan a reflexionar sobre el recurso al bricolaje ideológico y emocional, a fin de oponer unos actores políticos a otros en focos de tensión y en zonas de guerra. La legalidad internacional y el arsenal de leyes que regulan las relaciones internacionales es la única salida a los conflictos, siempre y cuando se democratice el Consejo de Seguridad de las Naciones Unidas, quizás en el marco de una reforma muy profunda parecida a la que llevó a la desaparición de la Liga de las Naciones y el nacimiento de la ONU justo después de la Segunda Guerra Mundial.

67. En la literatura islamista son frecuentes expresiones como: "nuestra constitución es el Corán", el "sistema político islámico", la "institución de la šūrà", "banca islámica", etc: ABDESATTAR, Abdellah (2007). Al Qur'an dustruna, Huli. Dar Iqa'a. 
- La represión del islamismo por parte de los regímenes de los países árabes e islámicos que llegaron a utilizar métodos criminales en su labor fue determinante en lo que se refiere a la radicalización que se efectuó en el nombre del islam. De hecho, hubo dos procesos de mutación hacia el radicalismo violento provocados por el comportamiento de los regímenes árabes. Primero, la transformación de muchos elementos islamistas que pasaron a nutrir las filas de grupos armados después de dar por fracasada la vía de la participación política en la sombra de regímenes totalitarios. Luego, más tarde, algunos salafíes tradicionales fueron seducidos por las ideas de grupos terroristas debido a otra razón ajena a la represión del islamismo, pero que tiene mucho que ver con la gestión del campo religioso por los regímenes árabes, especialmente el saudí.

De la exclusión y manipulación de las elecciones a las torturas, pasando por la instrumentalización de la justicia y la eliminación física. Todos los medios justificaban el fin de acabar con el islam político. El consentimiento tácito de los países occidentales contribuyó en ampliar el abismo que separa los islamistas y Occidente, sobre todo cuando se avaló la anulación de los resultados de las elecciones argelinas de 1991 y se procedió al boicot del gobierno de Hamas después de las elecciones de 2006. Es preocupante, por otra parte, constatar que ni siquiera existe un diálogo serio entre los países occidentales y los movimientos islamistas.

Hoy en día es más necesario que nunca cambiar los regímenes de los países árabes e islámicos instaurando la democracia que es la única vía válida para dar cabida a todas las corrientes políticas existentes en dichos países, incluidos los islamistas. El mejor aliado de los grupos terroristas en el mundo árabe e islámico es la injusticia que planea sobre aqueIlas poblaciones, la injusticia política y social implantada por los regímenes dictatoriales y la injusticia que se halla en algunos focos de tensión en países árabes y musulmanes. Democratizando los países árabes e islámicos y encontrando soluciones justas a conflictos como el de Oriente Medio o el problema afgano privaría al terrorismo global de los argumentos que viene esgrimiendo hasta hoy en día.

- El fracaso del islam oficial, que coincide con el retroceso de los movimientos islamistas, plantea un problema serio en lo que se refiere a la propagación del discurso radical de los grupos extremistas en el mundo islámico. La alianza entre los regímenes, árabes sobre todo, y los ulemas legitimistas acabó por socavar la legitimidad de los actores religiosos que actúan en el campo religioso controlado por dichos regímenes. El islam oficial, a través de la historia y en todas las regiones del mundo islámico, tuvo siempre una fecha de caducidad. Hoy en día es necesario, más que nunca, que haya un grupo de ulemas y alfaquíes libres e independientes para que vuelvan a desempeñar su papel social de siempre. Los únicos criterios de la validez de su discurso tienen que ser la moderación y la competencia. La distancia que puedan mantener hacia los regímenes de sus países no 
debería ser un motivo para excluirles como pasó con varios religiosos destacados que fueron literalmente desperdiciados en estos tiempos difíciles. Al mismo tiempo habrá que potenciar de nuevo universidades como Al Azhar, Al Qarawiyin o Az-zaituna, así como las asociaciones y plataformas que reúnen los actores principales del campo religioso, en un marco de autonomía total.

El hecho de rehabilitar la imagen del ulema independiente quiere decir que habrá un discurso que contará con toda la legitimidad necesaria, que partirá de los textos sagrados del islam para contrarrestar las interpretaciones deformadas de los ideólogos del terrorismo global. Hace siglos, el discurso de los jariyíes se desvaneció paulatinamente porque había voces escuchadas que lo desmontaban continuamente y, es lo que se echó en falta, cuando el discurso de Al Qaeda y los grupos afines a esta banda estaba arrasando.

- Los islamistas, árabes sobre todo, no han generado un nuevo discurso basado, por ejemplo, en modelos de partidos políticos desarrollados como el AKP turco. En el caso en que se democratice el escenario político en los países árabes, su participación en la transición democrática será inevitable. Sin embargo, dichas formaciones políticas tendrán que construir un discurso coherente, de tal manera que compagine los valores islámicos que defienden con las aportaciones de la democracia. El otro reto consistirá en aglutinar todas las corrientes conservadoras, desde el punto de vista religioso, a fin de dificultar la tarea de reclutamiento que los grupos extremistas están realizando, ofreciendo así una alternativa legal y fiable.

- Por fin, el diálogo político e intercultural es de suma importancia para evitar la acumulación de la incomprensión, el desprecio y el odio. Un diálogo serio, constructivo y que parta de las diferencias y las discrepancias es una plataforma sólida para construir la confianza mutua. Desde el inicio del proceso de Barcelona, en el año 1995, se realizaron varios encuentros en diferentes niveles. A lo largo de muchos años perdidos de las relaciones entre el Norte y el Sur, Occidente y Oriente, desfilaron en diferentes encuentros interlocutores que representaban otro a la medida del ego occidental. Un Otro plenamente occidentalizado que representa una minoría insignificante en los países árabes. Los encuentros interreligiosos fueron auténticas manifestaciones folklóricas donde se resaltaban, en un ambiente de flagrante hipocresía, los rasgos comunes de las religiones monoteístas y se pasaba por alto el auténtico problema de la utilización de la religión como un marcador de identidad y un sentimiento de pertenencia en los conflictos. Un sincero y verdadero diálogo permitiría, sin lugar a dudas, diagnosticar el origen del mayor malentendido de nuestra historia y determinar las causas del miedo al Otro que tantas calamidades ha provocado. 


\section{BIBLIOGRAFÍA}

- $\quad$ Abed, C. (1994). Algérie, le grand dérapage. L'Aube: La Tour d'Aigues.

- Allué, A. (2006). Libertad y seguridad en Europa. La protección del pluralismo y las experiencias de democracia militante. Revista de Derecho de la Unión Europea, N 10,-1.

- Anderson, B. (1996): L'imaginaire nationale: réflexions sur l'origine et l'essor du nationalisme. Paris: La Découverte.

- Charentenay, P. (1997). Quand le ciel trouble la terre. Religions et géopolitiqu. Paris : Brepols.

- $\quad$ Dahl, R. (2000). La democracia y sus críticos. Barcelona: Paidós.

- Del Águila, R. (1998). La razón de estado y sus vínculos con la ética política. Anuario de la Facultad de Derecho de la Universidad Autónoma de Madrid, № 2.

- Del Águila, R. (2008). Crítica de las ideologías. El peligro de los ideales, Madrid: Taurus.

- $\quad$ Dunn, J. (1996). La agonía del pensamiento político occidental. Cambridge: Cambridge University Press.

- $\quad$ Elorza, A. \& Reinares, F. (2004): El nuevo terrorismo islamista: del 11-S al 11-M, Madrid: Temas de hoy.

- Fanon, F. (1961): Les damnés de la terre. París: La Découverte.

- García, E. (2001). Sobre la democracia en el ámbito internacional. Isegoría: Revista de filosofía moral y política, № 24.

- Géze, F. (2005). Armée et nation en Algérie : l'irrémédiable divorce ?. Hérodote, vol. 1, no 116.

- González, R. (2009). Democracia e islamismo ¿Un matrimonio imposible?. Revista CIDOB d'afers internacionals, № 84 .

- Izquierdo, F. \& Farrés, G. (2008). La competición por el poder político entre el islam político y los militares en Turquía. REIM, № 5 .

- Jordán, J. (2003). Retos de la seguridad global. Revista Valenciana de Estudios Autonómicos, №: 41/42.

- Jordán, J. (2005). El terrorismo islamista en España. En Blanco, A. del Aguila R. \& Sabucedo, J (eds.) Madrid 11-m. un análisis del mal y de sus consecuencias. Madrid: Trotta.

- Kant, E. (1978). Principios metafísicos de la doctrina del Derecho. Méjico: Universidad Nacional Autónoma de Méjico.

- Magrhroori, R. \& Ramberg, B. (1982). Globalism versus Realism. International RelationsThird Debate. Boulder: Westview P. 
- Manin, B. (1998). Los principios del gobierno representativo. Madrid: Alianza Editorial.

- Radu, M. (2010). Spectres européens Le 'Londonistan' en tant que producteur et exportateur d'islamisme. Outre-Terre, № 24.

- Ramadan, T. (2002). Aux sources du renouveau musulman. Lyon: Tawhid.

- Roser, N. (2002). Religión y política: la concepción islámica. Salamanca: Sapere Aude.

- Samraoui, M. (2003). Chronique des années de sang. Algérie : comment les services secrets ont manipulé les groupes islamistes. París: Denoël

- Scheuer, M. (2004). Imperial Hubris. Why the West is loosing the war on Terror. Washington: Brassey's Inc.

- Souaidia, H. (2001). La sale Guerre, Paris: La Découverte.

- $\quad$ Tabari, Y. (1984). La Chronique. Histoire des prophètes et des rois, traducido por Hermann Zotenberg. Arles: Actes du Sud, vol. I.

- Thieux, L. (2007). Islamismo y democracia en Argelia. Francia y Estados Unidos frente al conflicto. Madrid: Ediciones del oriente y del mediterráneo.

- Tozy, M. (2000). Monarquía e islam político en Marruecos, traducción de Juan Vivanco. Barcelona: Bellaterra.

- Yous, N. (2000). Qui a tué à Bentalha?: chronique d'un massacre annoncé. Paris: La Découverte.

- Zarrouk, M. (2005). El islamismo marroquí y la democracia. Política Exterior, № 103, 1.

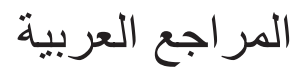

ابن تيمية، تقي الدين (2003) :السياسة الشرعية في إصلاح الراعي و الرعية ،دار الإيمان ، الإسكندرية.

\author{
أنس، عبد الله (2002) : ،ولادة الأفغان العربدار الساقي، لندن. \\ السيوطي، جلال الدين (1999):تاريخ الظلفاءدار الفكرن بيروت ،. \\ شحاتة، صيام (1988):العنف و الخطاب الديني دار سيناء، القاهرة 6.
}


ضريف، محمد (1999):الإسلاميون المغاربة .حسابات السياسة في العمل الإسلامي المجلة ، المغربية لعلم الإجتماع السياسي، النجاح، الدار البيضاء.

الطويل، كمال (2007): القاعدة و أخواتها .قصة الجهاديين العربدار الساقي، بيروت ،. الطيباوي، عبد اللطيف (1979) :محاضرات في تاريخ العرب و الإسلام ن دار الأندلس، بيروت.

عبد الستار، عبد الله (2007) :،القرآن دستورناحولي :دار اقرأ.

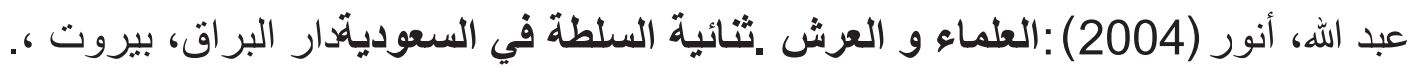
عمر، عبد الرحمن ماضي (1999):"مفهوم الشورى و الديمقر اطية" ، إشكالية العلاقة بين

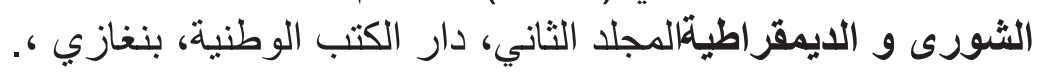

فرغلي، عبد الحفيظ (1990): الحافظ جلال الدين السيوطي ،الهيئة المصرية العامة للكتاب ، القاهرة.

القرضاوي، يوسف (2002): الإخوان المسلمون،مكتبة وهبة، القاهرة .

الماوردي، أبو حسن علي (1993): الأحكام السلطانية و الولايات الدينيةدار الأرقم، القاهرة ،. محفوظ، محمد (1988) : الذين ظلموارياض الريس للكتب و النشر، لندن ،.

الواعظي، أحمد (2002): الدولة الدينية ـتعاملات في الفكر السياسي الإسلامي، الغدير، بيروت.

ياسين، عبد السلام(1994) : حوار مع الفضلاء الديمقراطيينالأفق، الدار البيضاء ،. ياسين، عبد السلام (1996)::الشورى و الديمقراطية/الأق، الدار البيضاء 6. 